\title{
Phenotypic and Genotypic Characterization of Race TKTTF of Puccinia graminis f. sp. tritici that Caused a Wheat Stem Rust Epidemic in Southern Ethiopia in 2013-14
}

\author{
Pablo Olivera, Maria Newcomb, Les J. Szabo, Matthew Rouse, Jerry Johnson, Samuel Gale, Douglas G. Luster, \\ David Hodson, James A. Cox, Laura Burgin, Matt Hort, Christopher A. Gilligan, Mehran Patpour, \\ Annemarie F. Justesen, Mogens S. Hovmøller, Getaneh Woldeab, Endale Hailu, Bekele Hundie, \\ Kebede Tadesse, Michael Pumphrey, Ravi P. Singh, and Yue Jin
}

First and second authors: Department of Plant Pathology, University of Minnesota, St. Paul 55108; third, fourth, fifth, sixth, and twenty-second authors: United States Department of Agriculture-Agricultural Research Service (USDA-ARS) Cereal Disease Laboratory, University of Minnesota, St. Paul; seventh author: USDA-ARS Foreign Disease-Weed Science Research Unit, Ft. Detrick, MD 21702; eighth author: International Maize and Wheat Improvement Center (CIMMYT)-Ethiopia, Addis Ababa, Ethiopia; ninth and twelfth authors: Department of Plant Sciences, University of Cambridge, Downing Street, Cambridge, CB2 3EA, United Kingdom; tenth and eleventh authors: U.K. Met Office, Fitzroy Road, Exeter, Devon, EX1 3PB, United Kingdom; thirteenth, fourteenth, and fifteenth authors: Aarhus University, Department of Agroecology, Flakkebjerg, DK4200 Slagelse, Denmark; sixteenth and seventeenth authors: Ethiopian Institute of Agricultural Research, Ambo Agricultural Research Center, Ethiopia; eighteenth author: Ethiopian Institute of Agricultural Research, Kulumsa Agricultural Research Center, Assela, Ethiopia; nineteenth and twentieth authors: Department of Crop and Soil Sciences, Washington State University, Pullman 99164; and twenty-first author: CIMMYT, Apdo. Postal 6-641 06600 Mexico, D.F., Mexico.

Accepted for publication 4 March 2015.

\begin{abstract}
Olivera, P., Newcomb, M., Szabo, L. J., Rouse, M., Johnson, J., Gale, S., Luster, D. G., Hodson, D., Cox, J. A., Burgin, L., Hort, M., Gilligan, C. A., Patpour, M., Justesen, A. F., Hovmøller, M. S., Woldeab, G., Hailu, E., Hundie, B., Tadesse, K., Pumphrey, M., Singh, R. P., and Jin, Y. 2015. Phenotypic and genotypic characterization of race TKTTF of Puccinia graminis f. sp. tritici that caused a wheat stem rust epidemic in southern Ethiopia in 2013-14. Phytopathology 105:917-928.

A severe stem rust epidemic occurred in southern Ethiopia during November 2013 to January 2014, with yield losses close to $100 \%$ on the most widely grown wheat cultivar, 'Digalu'. Sixty-four stem rust samples collected from the regions were analyzed. A meteorological model for airborne spore dispersal was used to identify which regions were most likely to have been infected from postulated sites of initial infection.

TKTTF, TTKSK, RRTTF, and JRCQC. Race TKTTF was found to be the primary cause of the epidemic in the southeastern zones of Bale and Arsi. Isolates of race TKTTF were first identified in samples collected in early October 2013 from West Arsi. It was the sole or predominant race in 31 samples collected from Bale and Arsi zones after the stem rust epidemic was established. Race TTKSK was recovered from 15 samples from Bale and Arsi zones at low frequencies. Genotyping indicated that isolates of race TKTTF belongs to a genetic lineage that is different from the Ug99 race group and is composed of two distinct genetic types. Results from evaluation of selected germplasm indicated that some cultivars and breeding lines resistant to the Ug99 race group are susceptible to race TKTTF. Appearance of race TKTTF and the ensuing epidemic underlines the continuing threats and challenges posed by stem rust not only in East Africa but also to wider-scale wheat production.
\end{abstract} Based on the analyses of 106 single-pustule isolates derived from these samples, four races of Puccinia graminis f. sp. tritici were identified:

Ethiopia is the largest wheat producer in sub-Saharan Africa (FAOSTAT 2014). Wheat is a traditional staple food crop, cultivated by 5 million households on 1.6 million ha of land under rain-fed conditions. Wheat rusts, primarily stem rust caused by Puccinia graminis f. sp. tritici and stripe rust caused by $P$. striiformis f. sp. tritici, are major biotic constraints to wheat production in Ethiopia. Repeated rust epidemics have occurred in the last 20 years, notably stripe rust on 'Dashen' in 1988 (Zewde et al. 1990), and stem rust 'Enkoy' in 1993 and 1994 (Shank 1994). In 2010, a devastating stripe rust epidemic affected more than 600,000 ha and widely grown 'Kubsa' and 'Galema', and the Yr27-virulent strain of $P$. striiformis f. sp. tritici was attributed to be a major cause of this epidemic (www.wheatrust.org).

Corresponding author: J. Yue; E-mail address: yuejin@umn.edu

http://dx.doi.org/10.1094/PHYTO-11-14-0302-FI

This article is in the public domain and not copyrightable. It may be freely reprinted with customary crediting of the source. The American Phytopathological Society, 2015.
Additional keywords: dispersal model, surveillance.

Following the identification and spread of the $P$. graminis f. sp. tritici the Ug99 race group in East Africa, major national and international efforts have been made to develop and promote stemrust-resistant cultivars in Ethiopia (Singh et al. 2011). Heavy losses to stripe rust in 2010 provided a strong impetus for Ethiopian wheat farmers to adopt new rust-resistant cultivars. 'Digalu' (released in 2005) possesses good stripe rust resistance, high yield, and resistance to known races in the $\mathrm{Ug} 99$ group of $P$. graminis f. sp. tritici. Fast-track seed multiplication made it available quickly, and Digalu became a popular variety with Ethiopian farmers after 2010. By the 2013-14 main wheat season, Digalu was the most widely grown bread wheat cultivar in Ethiopia, planted on an estimated 500,000 ha. Intensive surveys undertaken in July 2013 during the short rain (Belg) season in southeastern and southern Ethiopia (Arsi, Bale, and SNNPR) found no stem rust infections on Digalu. Observations in field plots at Assasa, West Arsi on 10 October provided the first indication of increased susceptibility on Digalu, with stem rust severity scores of up to 50 disease severity and moderately susceptible (MS) to susceptible (S) responses (for more 
information on severity scoring, see Peterson et al. [1948]). No further observations of high susceptibility on Digalu were reported until November. High incidence but low severity of stem rust on Digalu was observed on 15 and 16 November in Robe district, Arsi zone. Stem rust at epidemic proportions on Digalu was subsequently reported from two adjacent districts (Agarfa and Gasera) in Bale zone on 23 November, although stem rust was likely present in these districts for several weeks prior to the formal reports. Agarfa and Gasera districts represented the core of the epidemic; however, subsequent spread was observed during the period of November 2013 to January 2014. In total, 27 districts in southeastern and southern Ethiopia were affected to some extent based on field surveys (Fig. 1). Over 100,000 ha were planted to wheat in these districts, with an estimated 20,000 to 40,000 ha likely planted to Digalu and affected by stem rust. Digalu was observed to be highly susceptible, with 80 to $100 \%$ disease severity and moderately susceptible to susceptible infection responses throughout the affected region. Wheat production in this region of Ethiopia is asynchronous with the majority of Ethiopian wheat-growing areas, being 2 to 3 months later due to the presence of a prior Belg season. This asynchrony resulted in no further spread beyond southeastern and southern Ethiopia during the 2013-14 crop season because the majority of wheat crops in other areas had already been harvested. A crop loss assessment in three affected districts (Agarfa, Gasera, and Sinana) in Bale zone recorded losses of up to $92 \%$ on Digalu compared with harvested yields in 2012. Measured harvested yields in the worst-affected district (Gasera) were as low as $0.3 \mathrm{t} / \mathrm{ha}$. Average losses on Digalu across all three districts, compared with reported yields on Digalu from the same fields in 2012-13, were $51 \%$.
The objectives of this study were to identify and characterize the races of $P$. graminis $\mathrm{f}$. sp. tritici that caused the stem rust epidemic in southeast Ethiopia, genotype representative isolates, and determine the level of vulnerability of Ethiopian and international bread wheat breeding materials to this potentially new virulence combination.

\section{MATERIALS AND METHODS}

Sample collection and storage. Dried samples of $P$. graminis f. sp. tritici-infected wheat tissue were mailed to two rust diagnostic laboratories: United States Department of Agriculture-Agricultural Research Service (USDA-ARS) Cereal Disease Laboratory (CDL), St. Paul, MN and Aarhus University, Global Rust Reference Center (GRRC), Flakkebjerg, Denmark. Duplicated samples were also received by the Ethiopian Institute of Agricultural Research Ambo Plant Protection Research Center. Fifty-nine samples (13ETH01 to -59) of infected stems collected from bread and durum wheat cultivars and lines from 2 October 2013 to 21 January 2014 were sent to CDL, and five samples (13ETH60 to -64) collected in October to November 2013 were mailed to GRRC. Collection sites were located in eight Ethiopian wheat-growing zones: Arsi, West Arsi, Bale, Selti, East Shewa, West Shewa, North Shewa, and West Gojam (Fig. 2). Passport data of the samples are given in Table 1. Each sample consisted of 10 to 15 pieces of stem tissue of approximately $10 \mathrm{~cm}$ in length bearing moderately susceptible to susceptible pustules. Stem and leaf sheath tissue were kept in glassine or paper bags and air dried at room temperature. Dried samples were mailed to the two laboratories using an international express courier service with a transit time of approximately 5 days.

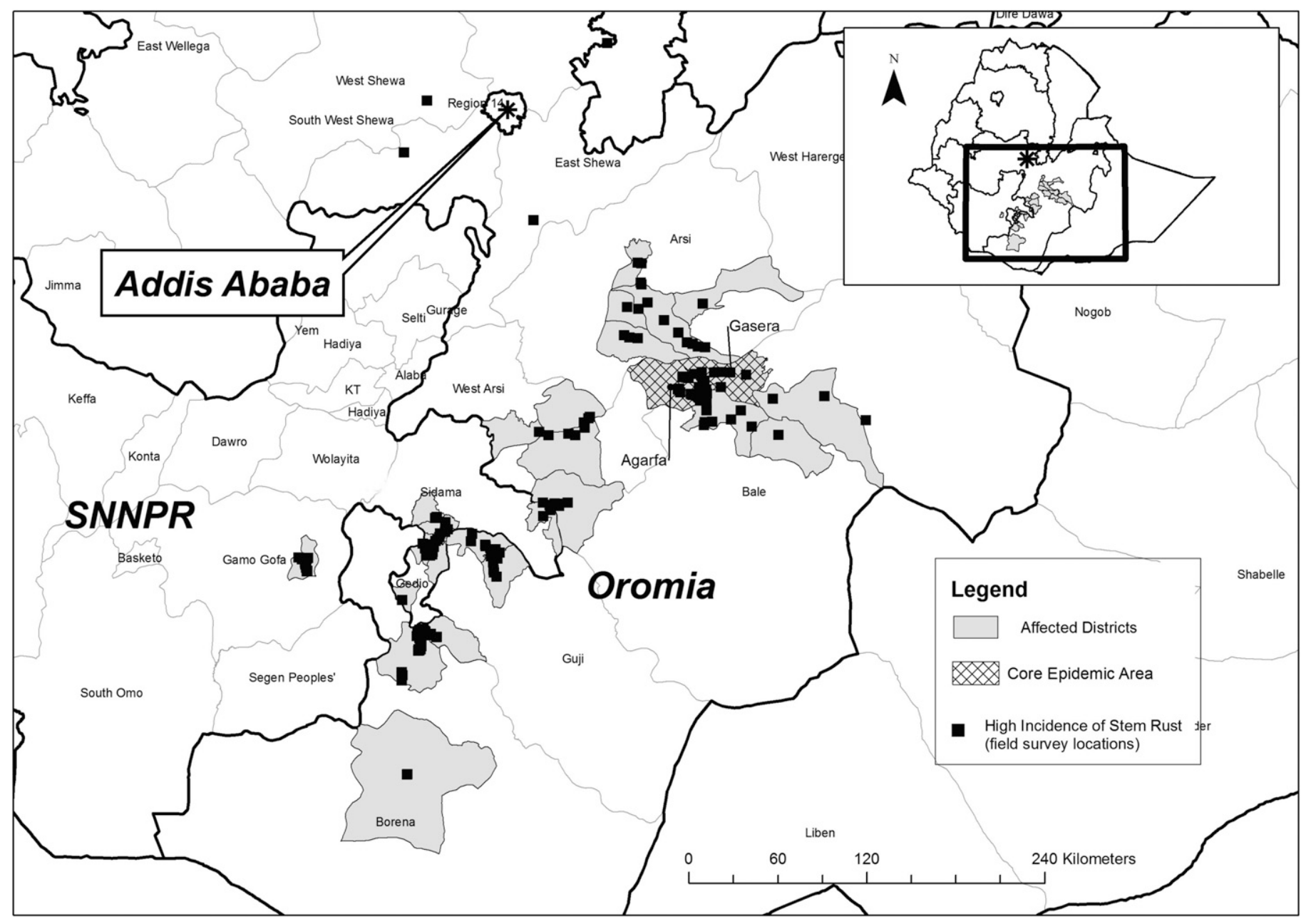

Fig. 1. Districts affected by a stem rust epidemic caused by race TKTTF of Puccinia graminis f. sp. tritici in Ethiopia from November 2013 to January 2014. 
Shipping protocol was followed according to USDA Animal and Plant Health Inspection Service permit conditions for handling international cultures of $P$. graminis $\mathrm{f}$. sp. tritici. Samples that arrived at the $\mathrm{CDL}$ before 1 December were stored in a $-80^{\circ} \mathrm{C}$ freezer, whereas samples received after 1 December were processed upon arrival. Urediniospores from each sample were collected into three to four gelatin capsules (size 00 ) and stored at $-80^{\circ} \mathrm{C}$. Samples arriving at GRRC were processed upon arrival and recovered spore samples were stored in liquid nitrogen until further use.

Race identification. The North American stem rust differential set (Roelfs et al. 1993; Roelfs and Martens 1988) that was modified to further delineate $P$. graminis $\mathrm{f}$. $\mathrm{sp}$. tritici races in the TTKS race group (Jin et al. 2008) was used for race identification. In addition, all samples at CDL were further characterized on 20 monogenic lines carrying the following resistance genes: $\operatorname{Sr} 7 a, \operatorname{Sr} 13, \mathrm{Sr} 22$, Sr25, Sr26, Sr27, Sr31, Sr32, Sr33, Sr35, Sr37, Sr39, Sr40, Sr44, Sr45, Sr47, Sr50, SrSatu, SrTt-3, and the 1A.1R translocation in winter wheat. Durum wheat 'Iumillo' $(\operatorname{Sr} 9 g, 12,+)$ and 'Leeds' $(\mathrm{Sr} 9 e, 13,+)$ were also included in the evaluation. One capsule per sample was removed from the $-80^{\circ} \mathrm{C}$ freezer, heat shocked $\left(45^{\circ} \mathrm{C}\right.$ for $15 \mathrm{~min}$ ), and then placed in a rehydration chamber $(80 \%$ relative humidity maintained by a $\mathrm{KOH}$ solution) for a period of $4 \mathrm{~h}$ (Jin et al. 2008). Five seedlings of each differential and additional resistant lines were inoculated with a bulk collection of spores on fully expanded primary leaves at 8 to 9 days after planting. Experimental procedures for inoculation, incubation, and disease assessment were done as described by Jin et al. (2007). Singlepustule isolates were derived from individual plants after evaluation on the differential and additional lines. One to four pustules were isolated from each original collection. Incubation and collection of urediniospores from each single pustule was done as described by Jin et al. (2008). Urediniospores from the original samples and the pure cultures derived from single-pustule procedure were increased on the susceptible wheat Line E and McNair 701 (CItr 15288) in pots enclosed in cellophane bags (Zellglas Boden-Beutel, Germany) and stored at $-80^{\circ} \mathrm{C}$. Pure cultures were evaluated two to three times on differential lines before a race name was designated. Race designation was based on the letter code proposed by Roelfs and Martens (1988).

Race identification at GRRC and Ambo generally followed the procedures described above, except that at GRRC isolates were recovered on seedlings of 'Morocco' wheat. The seedlings were treated with $5 \mathrm{ml}$ of $0.5 \%$ Antergon MH180 growth regulator (Nordisk Alkali, Randers, Denmark) to prevent further leaf formation and enhance spore production. After removal from the 24-h dew chamber, inoculated plants for spore increase and for differential set assays were incubated in spore-proof, climatecontrolled cabinets at 19 to $21^{\circ} \mathrm{C}$ (day) and 16 to $18^{\circ} \mathrm{C}$ (night) with gradually changing temperature and a $16-\mathrm{h}$ photoperiod from natural and supplemental light at $300 \mu \mathrm{E} / \mathrm{m}^{2} / \mathrm{s}$ PAR.

In order to increase the probability of recovering $P$. graminis f. sp. tritici isolates with specific virulence that might be present at a low frequency, 110 to 120 plants of lines ISr11-Ra $(\operatorname{Srl1})$ and $\mathrm{Sr} 31 / 6 *$ LMPG $(\mathrm{Sr} 31)$ were included in the evaluation for 15 samples collected from Bale and Arsi regions. At the time of disease assessment, the number of uredinia and infection sites

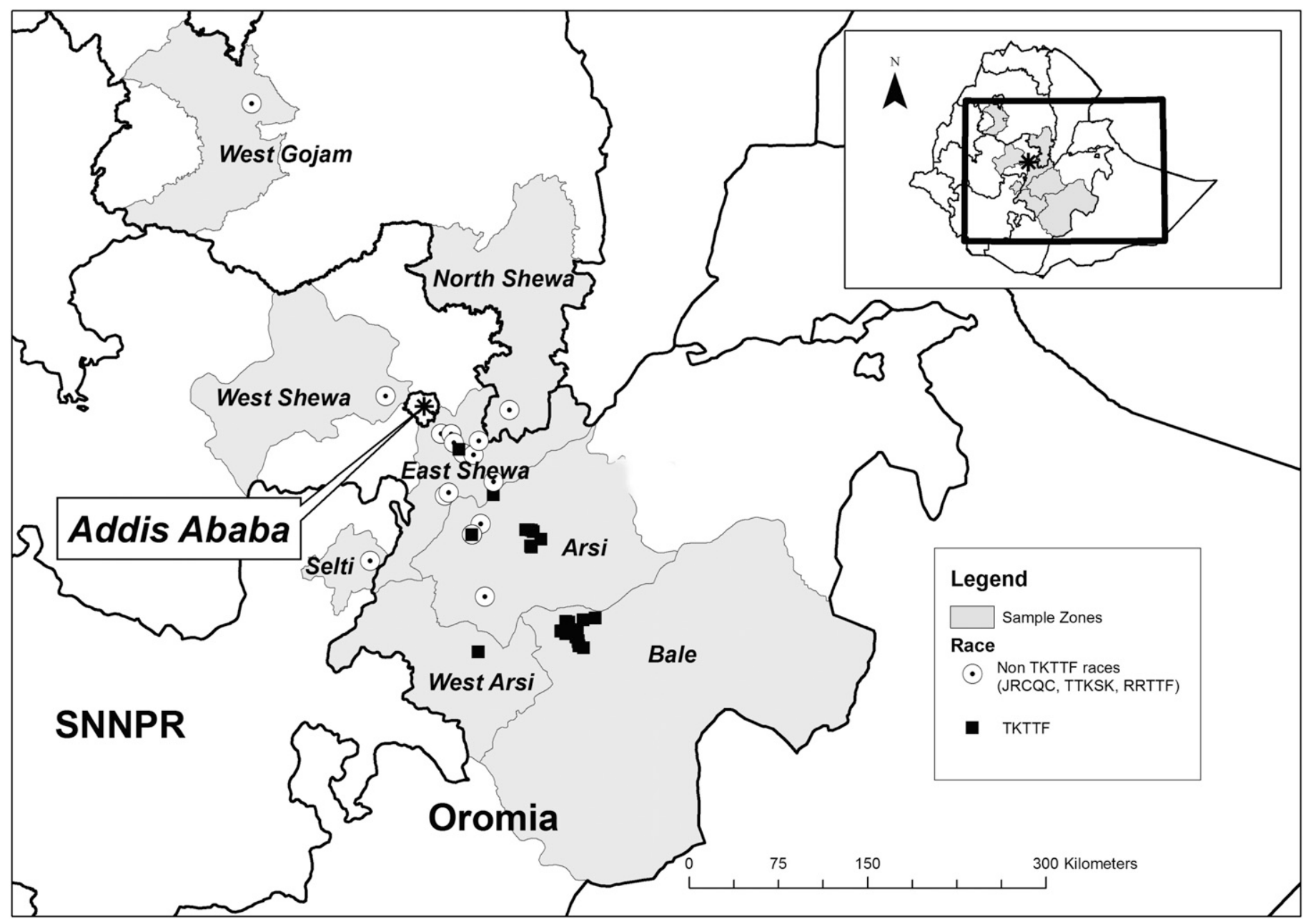

Fig. 2. Wheat stem rust sample collection sites (October 2013 to January 2014) and the distribution of race TKTTF and non-TKTTF races of Puccinia graminis f. sp. tritici. 
on 20 randomly selected leaves was counted from both sets of plants, infection types (ITs) were recorded, and the frequency of each IT was calculated. Uredinia of $P$. graminis f. sp. tritici exhibiting high ITs were randomly selected, and urediniospores were collected and race-typed following the abovementioned procedures.

Genotyping of $\boldsymbol{P}$. graminis f. sp. tritici isolates. DNA was extracted from either purified $P$. graminis f. sp. tritici urediniospores

TABLE 1. Races of Puccinia graminis f. sp. tritici identified from samples collected in Ethiopia from October 2013 until January 2014, according to collection date and site

\begin{tabular}{|c|c|c|c|c|c|c|c|c|c|}
\hline \multirow[b]{2}{*}{ Sample ID } & \multirow[b]{2}{*}{ Collection date } & \multicolumn{5}{|c|}{ Collection site } & \multirow[b]{2}{*}{ Host } & \multirow[b]{2}{*}{ Variety } & \multirow[b]{2}{*}{ Races identified $^{\mathrm{b}}$} \\
\hline & & Zone & Location $^{\mathrm{a}}$ & Latitude & Longitude & Altitude (m) & & & \\
\hline 13ETH60 & 3 October 2013 & Arsi & Kulumsa & 8.01514 & 39.1579 & 2,214 & Bread wheat & Hidasse & TTKSK \\
\hline 13ETH61 & 3 October 2013 & East Shewa & Debre Zeit & 8.77164 & 39.00023 & 1,897 & Bread wheat & Sr31 differential & TTKSK \\
\hline 13ETH62 & 10 October 2013 & West Arsi & Assasa & 7.125422 & 39.20741 & 2,381 & Bread wheat & Digalu & TKTTF \\
\hline 13ETH49 & 10 October 2013 & West Arsi & Assasa & 7.125422 & 39.20741 & 2,381 & Bread wheat & Digalu & TKTTF \\
\hline 13ETH50 & 10 October 2013 & West Arsi & Assasa & 7.125422 & 39.20741 & 2,381 & Bread wheat & Digalu & TKTTF + TTKSK \\
\hline 13ETH15 & 19 October 2013 & West Goham & Adet R.C. & 11.278 & 37.4912 & 2,242 & Bread wheat & Digalu & RRTTF \\
\hline 13ETH13 & 20 October 2013 & Arsi & Kulumsa R.C. & 8.0151 & 39.1579 & 2,214 & Bread wheat & Hidase & TTKSK + TKTTF \\
\hline 13ETH24 & 21 October 2013 & East Shewa & Denbi R.S. & 8.7739 & 38.925 & 1,910 & Bread wheat & Unknown & TTKSK \\
\hline 13ETH25 & 21 October 2013 & East Shewa & Denbi R.S. & 8.7739 & 38.925 & 1,910 & Durum wheat & Unknown & JRCQC \\
\hline 13ETH26 & 22 October 2013 & East Shewa & Debre Zeit R.C. & 8.7716 & 39.0002 & 1,897 & Bread wheat & Danda'a & TTKSK \\
\hline 13ETH27 & 22 October 2013 & East Shewa & Debre Zeit R.C. & 8.7716 & 39.0002 & 1,897 & Bread wheat & Combination & JRCQC \\
\hline 13ETH28 & 22 October 2013 & East Shewa & Debre Zeit R.C. & 8.7716 & 39.0002 & 1,897 & Bread wheat & Kota/6*LMPG & JRCQC \\
\hline 13ETH29 & 22 October 2013 & East Shewa & Debre Zeit R.C. & 8.7716 & 39.0002 & 1,897 & Bread wheat & LcSr25Ars & JRCQC \\
\hline 13ЕТН30 & 22 October 2013 & East Shewa & Debre Zeit R.C. & 8.7716 & 39.0002 & 1,897 & Bread wheat & RL5405 & JRCQC \\
\hline 13ETH31 & 22 October 2013 & East Shewa & Debre Zeit R.C. & 8.7716 & 39.0002 & 1,897 & Emmer wheat & Unknown & JRCQC \\
\hline 13ЕTH37 & 23 October 2013 & East Shewa & Alem Tena & 8.3098 & 38.9524 & 1,644 & Durum wheat & Unknown & TTKSK \\
\hline 13ЕТН38 & 23 October 2013 & East Shewa & Welenchiti & 8.3323 & 38.9808 & 1,602 & Bread wheat & Kubsa & TTKSK \\
\hline 13ЕTH32 & 24 October 2013 & East Shewa & Debre Zeit & 8.7055 & 39.0218 & 1,891 & Bread wheat & Kubsa & TTKSK \\
\hline 13ETH33 & 24 October 2013 & East Shewa & Mojo & 8.6251 & 39.0927 & 1,806 & Bread wheat & Kubsa & TTKSK \\
\hline 13ETH34 & 24 October 2013 & East Shewa & Adama & 8.616 & 39.1686 & 1,887 & Bread wheat & Kubsa & TTKSK \\
\hline 13ETH35 & 24 October 2013 & East Shewa & Deda & 8.7194 & 39.2105 & 2,150 & Bread wheat & Danda'a & TTKSK \\
\hline 13ЕТН36 & 24 October 2013 & North Shewa & Minjar R.S. & 8.955 & 39.4401 & 1,757 & Durum wheat & Unknown & TTKSK + RRTTF \\
\hline 13ETH12 & 24 October 2013 & Selti & Lanfro & 7.815053 & 38.388203 & 1,872 & Bread wheat & Jefferson & TTKSK \\
\hline 13ETH10 & 25 October 2013 & East Shewa & Ude & 8.6599 & 32.059 & 1,864 & Bread wheat & Digalu & TKTTF \\
\hline 13ETH08 & 25 October 2013 & Arsi & Shakee Sharara & 8.09521 & 39.223837 & 2,209 & Bread wheat & Hidase & TTKSK \\
\hline 13ЕTH09 & 25 October 2013 & Arsi & Dhera R.S. & 8.319 & 39.3209 & 1,686 & Bread wheat & Kakaba & TKTTF + TTKSK \\
\hline 13ETH11 & 25 October 2013 & Arsi & Melkassa R.C. & 8.4141 & 39.3208 & 1,533 & Bread wheat & Unknown & TTKSK \\
\hline 13ETH03 & 28 October 2013 & Arsi & Kulumsa R.C. & 8.0151 & 39.1579 & 2,214 & Bread wheat & Shorima & TTKSK \\
\hline 13ETH05 & 28 October 2013 & Arsi & Kulumsa R.C. & 8.0151 & 39.1579 & 2,214 & Bread wheat & Shorima & TTKSK \\
\hline 13ETH01 & 29 October 2013 & Arsi & Kulumsa R.C. & 8.0151 & 39.1579 & 2,214 & Bread wheat & Kingbird & TTKSK \\
\hline 13ETH02 & 29 October 2013 & Arsi & Kulumsa R.C. & 8.0151 & 39.1579 & 2,214 & Bread wheat & Danda'a & TTKSK \\
\hline 13ETH06 & 29 October 2013 & Arsi & Kulumsa R.C. & 8.0151 & 39.1579 & 2,214 & Bread wheat & Danda'a & TTKSK \\
\hline 13ЕTH07 & 29 October 2013 & Arsi & Kulumsa R.C. & 8.0151 & 39.1579 & 2,214 & Bread wheat & Digalu & TKTTF + TTKSK \\
\hline 13ETH04 & 30 October 2013 & Arsi & Kulumsa R.C. & 8.0151 & 39.1579 & 2,214 & Bread wheat & Shorima & TTKSK \\
\hline 13ETH14 & 30 October 2013 & Arsi & Bekoji & 7.5443 & 39.2559 & 2,812 & Bread wheat & Unknown & TTKSK \\
\hline 13ETH16 & 4 November 2013 & West Shewa & Holetta R.C. & 9.0607 & 38.5051 & 2,401 & Bread wheat & Unknown & RRTTF \\
\hline 13ETH17 & 4 November 2013 & West Shewa & Holetta R.C. & 9.0607 & 38.5051 & 2,401 & Durum Wheat & Unknown & $\mathrm{JRCQC}+\mathrm{RRTTF}$ \\
\hline 13ETH63 & 8 November 2013 & Arsi & Arsi Robe & 7.884212 & 39.628016 & 2,443 & Bread wheat & Unknown & TTKSK \\
\hline 13ETH64 & 8 November 2013 & Arsi & Meraro & 7.410474 & 39.257877 & 2,978 & Bread wheat & Unknown & TTKSK \\
\hline 13ETH18 & 26 November 2013 & Bale & Agarfa & 7.237 & 39.9546 & 2,382 & Bread wheat & Danda'a & TKTTF + TTKSK \\
\hline 13ETH19 & 26 November 2013 & Bale & Agarfa & 7.3595 & 39.8688 & 2,377 & Bread wheat & Danda'a & TKTTF + TTKSK \\
\hline 13ETH20 & 26 November 2013 & Bale & Agarfa & 7.2136 & 39.964 & 2,365 & Bread wheat & Digalu & TKTTF + TTKSK \\
\hline 13ETH21 & 26 November 2013 & Bale & Agarfa & 7.2391 & 39.9514 & 2,422 & Bread wheat & Digalu & TKTTF + TTKSK \\
\hline 13ETH22 & 26 November 2013 & Bale & Agarfa & 7.2864 & 39.8375 & 2,410 & Bread wheat & Digalu & TKTTF + TTKSK \\
\hline $13 \mathrm{ETH} 23$ & 26 November 2013 & Bale & Agarfa & 7.3517 & 39.8934 & 2,322 & Bread wheat & Digalu & TKTTF + TTKSK \\
\hline 13ЕТН39 & 03 December 2013 & Bale & Sinana & 7.17241 & 39.96988 & 2,406 & Bread wheat & Digalu & TKTTF \\
\hline $13 \mathrm{ETH} 40$ & 3 December 2013 & Bale & Agarfa & 7.23993 & 39.94786 & 2,420 & Bread wheat & Danda'a & TKTTF + TTKSK \\
\hline 13ETH41 & 3 December 2013 & Bale & Agarfa & 7.26406 & 39.86922 & 2,510 & Bread wheat & Danda'a & TKTTF \\
\hline 13ETH42 & 3 December 2013 & Bale & Agarfa & 7.284 & 39.83201 & 2,442 & Bread wheat & Digalu & TKTTF \\
\hline 13ETH43 & 3 December 2013 & Bale & Agarfa & 7.35281 & 39.88284 & 2,376 & Bread wheat & Hidasse & TKTTF \\
\hline 13ETH44 & 3 December 2013 & Bale & Robe & 7.15747 & 40.00434 & 2,444 & Bread wheat & Digalu & TKTTF + TTKSK \\
\hline 13ETH45 & 3 December 2013 & Bale & Gasera & 7.36907 & 40.0018 & 2,340 & Bread wheat & Digalu & TKTTF + TTKSK \\
\hline 13ETH46 & 3 December 2013 & Bale & Gasera & 7.38352 & 40.09188 & 2,337 & Bread wheat & Digalu & TKTTF \\
\hline $13 \mathrm{ETH} 47$ & 3 December 2013 & Bale & Robe & 7.20527 & 39.96315 & 2,377 & Bread wheat & Danda'a & TKTTF \\
\hline 13ETH48 & 3 December 2013 & Bale & Sinana & 7.294738 & 39.958571 & 2,373 & Bread wheat & Digalu & TKTTF \\
\hline 13ETH51 & 21 January 2014 & Arsi & Diksis & 8.0531 & 39.5657 & 2,685 & Bread wheat & Digalu & TKTTF \\
\hline 13ETH52 & 21 January 2014 & Arsi & Diksis & 8.0516 & 39.587 & 2,635 & Bread wheat & Digalu & TKTTF \\
\hline 13ETH53 & 21 January 2014 & Arsi & Sude & 8.0381 & 39.6229 & 2,539 & Bread wheat & Danda'a & TKTTF \\
\hline 13ETH54 & 21 January 2014 & Arsi & Hule, Sude & 7.9817 & 39.68 & 2,416 & Bread wheat & Danda'a & TKTTF \\
\hline 13ETH55 & 21 January 2014 & Arsi & Diksis & 8.0481 & 39.6088 & 2,582 & Bread wheat & Digalu & TKTTF \\
\hline 13ETH56 & 21 January 2014 & Arsi & Diksis & 8.0481 & 39.6088 & 2,582 & Bread wheat & Digalu & TKTTF \\
\hline 13ETH57 & 21 January 2014 & Arsi & Robe & 7.9204 & 39.6086 & 2,462 & Bread wheat & Digalu & TKTTF \\
\hline 13ETH58 & 21 January 2014 & Arsi & Robe & 7.9301 & 39.6048 & 2,462 & Bread wheat & Digalu & TKTTF \\
\hline 13ETH59 & 21 January 2014 & Arsi & Robe & 7.9301 & 39.6048 & 2,462 & Bread wheat & Digalu & TKTTF \\
\hline
\end{tabular}

${ }^{a}$ R.C. $=$ Research Center and R.S. = Research Station.

$\mathrm{b}$ Race nomenclature was based on Jin et al. (2007), and predominant race in the sample was listed first. 
(25 to $50 \mathrm{mg}$ ) or a 25-mm section of $P$. graminis f. sp. tritici-infected dry wheat leaf material. Starting material was pulverized with 1-mm glass beads (Lysing matrix C; MP Biomedicals, Santa Ana, CA) by shaking in a FastPrep-24 5G (MP Biomedicals) at a speed setting of 4 for $20 \mathrm{~s}$, twice. DNA isolations were performed using the OmniPrep DNA extraction kit (G-Biosciences, St. Louis) as described by the manufacturer. Amount and purity of the DNA was determined using a Nanodrop Model ND-1000 (NanoDrop Products, Wilmington, DE).

A custom 1,536-single-nucleotide protein (SNP) GoldenGate Chip (PgtSNP Chip) (L. Szabo and J. Johnson, unpublished data) was used for genotyping. The SNP chip assay was performed as described by the manufacturer (Illumina, San Diego, CA) using $500 \mathrm{ng}$ of DNA per sample, and each sample was run in duplicate. Chips were read on an Illumina iScan instrument and genotyping calls were made using Illumina GenomeStudio software (v2011.1), with Genotyping module (v1.9.4). The SNP data set was refined from 1,536 to 918 by removing markers with GenTrain score $<0.6$, $10 \% \mathrm{GC}<0.6$, missing data (no calls), and inconsistency between replicates.

Phylogenetic analysis of the data was performed using R (version 3.1.2; R Core Team, 2014), with the package 'Poppr' version 1.1.2 (Kamvar et al. 2014) installed. The following packages and their libraries were also imported for analysis: Ape v3.1-4 (Paradis et al. 2004), Adegenet v1.4-2 (Jombart 2008), and Pegas v 0.6 (Paradis 2010). Trees were constructed with the 'aboot' function. Parameters were Nei's distance (Nei 1972, 1978), neighbor-joining (Saitou and Nei 1987), a sample of 5,000 bootstrap replicates, and cutoff value of $80 \%$. Discriminant analysis of principal components (DAPC) (Jombart et al. 2010) was carried out using the 'dapc' function in Poppr. The first four principal components were retained for the analysis, which accounted for over $98 \%$ of the cumulative variance. Data were displayed using 'scatter' and 'compoplot' functions. A minimum spanning network was generated using 'msn' function with Nei's distance matrix of a subset of 41 $P$. graminis f. sp. tritici isolates from Ethiopia, which was organized by sample location.

Seedling evaluation of wheat germplasm. Isolate 13ETH18-1 derived from a sample collected in Bale zone was increased on the Sr36 differential line W2691SrTt-1 for use in seedling screening assays conducted inside a University of Minnesota Biosafety Level 3 facility. Seedling screening entries included 66 Ethiopian cultivars and 66 Ethiopian advanced breeding lines that are candidates for being replacements of the current cultivars, as well as selections from the eighth and ninth Stem Rust Resistance Screening Nurseries (SRRSN) from the International Maize and Wheat Improvement Center (CIMMYT). The SRRSN selections were based on field stem rust resistance evaluated at the Kenya Agricultural Research Institute stem rust nursery at Njoro in the preceding years.

Methods for planting, seedling maintenance, and inoculations were the same as described above for race analysis on differential sets. All inoculations were conducted with fresh urediniospores collected from secondary increases on the susceptible wheat line McNair 701. Seedling ITs were determined at 12 to 14 days postinoculation following the 0-to-4 scale developed by Stakman et al. (1962). ITs greater than or equal to were categorized as susceptible reactions, while those less than 3 - were categorized as resistant reactions. Seedling assays were conducted a single time per entry.

Modeling airborne spore dispersal. In order to assess the risk of pathogen spread via airborne dispersal of spores from the hypothesized locations of initial infection in Agarfa and Gasera within the Bale zone, we used the U.K. Met Office Numerical Atmospheric-dispersion Modeling Environment (NAME) model (Jones et al. 2007). NAME is a Lagrangian, stochastic particle dispersion model designed to predict the atmospheric transport and deposition of airborne substances to the ground surface. The model accounts for solar-induced loss of spore viability during transport, and for wet and dry spore deposition processes. The dispersal processes were driven by high-resolution meteorological data (interpolated from $25 \mathrm{~km}$ ) from the U.K. Met Office Unified Model (Brown et al. 2012), with 3-hourly input data for a range of variables that include air temperature, wind speed and direction, and precipitation rate. Spore release was simulated daily between 09:00 and 15:00 local time. The maximum spore lifetime during transport was limited to 3 days, consistent with Singh et al. (2008), with the proportion of viable spores decreasing exponentially to a threshold of $1 \%$ by 3 days, giving a half-life of approximately $11 \mathrm{~h}$. Sensitivity analysis, extending the survival to a maximum of 10 days, resulted in an extended dispersal range; however, wind directions were such that the qualitative radial patterns of regions receiving high and low spore deposition densities around the infection sources did not change. Parameters for wet and dry deposition were selected to be appropriate for spore sizes (Jones et al. 2007) and the spatial resolution of the spore deposition-sampling grid was set to 5 arcmin, approximately $9 \mathrm{~km}$ at the equator.

\section{RESULTS}

From 59 P. graminis f. sp. tritici samples collected in Ethiopia from October 2013 through January 2014 and sent to the CDL, 101 single pustules were derived. In addition, five isolates were derived from the samples submitted to GRRC in 2013. From these isolates, four races of $P$. graminis f. sp. tritici were identified: TKTTF, TTKSK, JRCQC, and RRTTF (Table 1).

Zones of East, North, and West Shewa and West Gojam. In the zones of Shewa and Gojam, the wheat-growing period extends from June to November, with stem rust samples collected from October through early November. Both bread wheat and durum are cultivated in these regions. In samples collected from the zones of West Gojam and West, North, and East Shewa, P. graminis f. sp. tritici races TTKSK, JRCQC, and RRTTF predominated; only one sample collected at Ude, East Shewa on 25 October was confirmed to be race TKTTF. The most frequent race observed was TTKSK, which was most often found in samples collected from bread wheat varieties planted in farmer's fields (Table 1). Isolates of race RRTTF were found in four geographic zones in late 2013 (Table 1). This race was identified from samples collected from both bread wheat and durum. The virulence profile of race RRTTF from samples collected in Ethiopia in 2013 (Table 2) was identical to that of isolates of race RRTTF first reported in Ethiopia and Yemen in 2007 (Fetch 2009) and Pakistan in 2009 (Iqbal et al. 2010). Isolates of race JRCQC were observed primarily at the Debre Zeit Research Center, where it is used as inoculum in the durum stem rust field nursery. It was also collected from durum wheat at Holetta Research Center (West Shewa) and Denbi Research Station (East Shewa), the later located less than $10 \mathrm{~km}$ from the Debre Zeit stem rust nursery. All the JRCQC isolates from different locations had an identical virulence profile compared with each other (Table 2) and with previously described collections made in 2009 at the Debre Zeit stem rust nursery (Olivera et al. 2012).

Zones of Arsi, West Arsi, Bale (Oromia region), and Selti (SNNPR). In the southeast zones of Arsi, West Arsi, Bale, and Selti, bread wheat is the predominant crop, and Digalu is currently one of the most important wheat varieties, occupying approximately 30 to $40 \%$ of wheat acreage. In Arsi, West Arsi, and Selti, the majority of wheat is planted at the same time as in Shewa, and stem rust samples were collected in October. Pockets of wheat in Arsi zone (e.g., Arsi Robe, Diksis, and Sude districts) were late planted in August to September and stem rust samples were collected from November through January. In Bale zone and parts of SNNPR, wheat is grown in two seasons: a short Belg season planted in March to April and harvested in July, and a main season planted in August and harvested in November to January. Stem rust samples are usually collected in either July (Belg season) or from November to January (main season). 
Race TKTTF was first identified from stem rust samples collected on Digalu from Assasa, West Arsi in early October 2013 (10 October). In late October, race TKTTF was identified from three samples collected from Arsi (Kulumsa Research Center, 20 and 29 October; and Dhera Research Station, 25 October) (Table 1). From the remaining 11 Arsi samples collected in October, the only race identified was TTKSK. However, once the localized stem rust epidemic started in Bale and Arsi zones of Ethiopia, 27 of 29 samples collected in the period November 2013 to January 2014 yielded only race TKTTF (16 samples) or were collected where isolates of race TKTTF were dominant (11 samples) (Table 1). Race TTKSK was identified from two samples only, which were not collected from Digalu.

Isolate 13ETH18-1 (race TKTTF) produced high ITs on differential lines carrying $\operatorname{Sr} 5, \operatorname{Sr} 6, \operatorname{Sr} 7 b, \operatorname{Sr} 8 a, \operatorname{Sr} 9 a, \operatorname{Sr} 9 b, \operatorname{Sr} 9 d$, Sr9e, Sr9g, Sr10, Sr17, Sr21, Sr30, Sr36, Sr38, SrTmp, and SrMcN (Table 2). The differences between isolates of race TKTTF and TTKSK on these differential lines is shown in Figure 3. In a few replications, intermediate ITs on $\mathrm{Sr} 9 b$ inoculated with isolate 13ETH18-1 were observed. Thus, it is uncertain whether isolates of TKTTF are actually virulent on $S r 9 b$. $P$. graminis f. sp. tritici race TKTTF is highly virulent on Digalu, producing disease severities up to $100-\mathrm{S}$ in unsprayed fields (data not shown). Isolates of race TKTTF were avirulent to all the additional stem rust resistance genes tested in this study (Table 3). The uredinial morphology of $P$. graminis $\mathrm{f}$. sp. tritici isolates of race TKTTF is similar to that observed in isolates of race TRTTF (Olivera et al. 2012) and RRTTF, in that the color of uredinia is darker than normal and the rupture of the epidermal tissue over the uredinia is delayed. These morphological characteristics are distinct from other common $P$. graminis f. sp. tritici isolates.

In some stem rust samples in which race TKTTF was predominant, the presence of pustules with high IT on differential lines ISr11-Ra (Sr11) and Sr31/6*LMPG (Sr31) was observed at low frequencies. These "off types" suggested that these samples contained $P$. graminis f. sp. tritici TTKSK-like races. In order to

TABLE 2. Infection types (ITs) observed on stem rust differentials produced by inoculating races TKTTF, TTKSK, JRCQC, and RRTTF of Puccinia graminis f. sp. tritici collected in Ethiopia in the period during October 2013 to January 2014

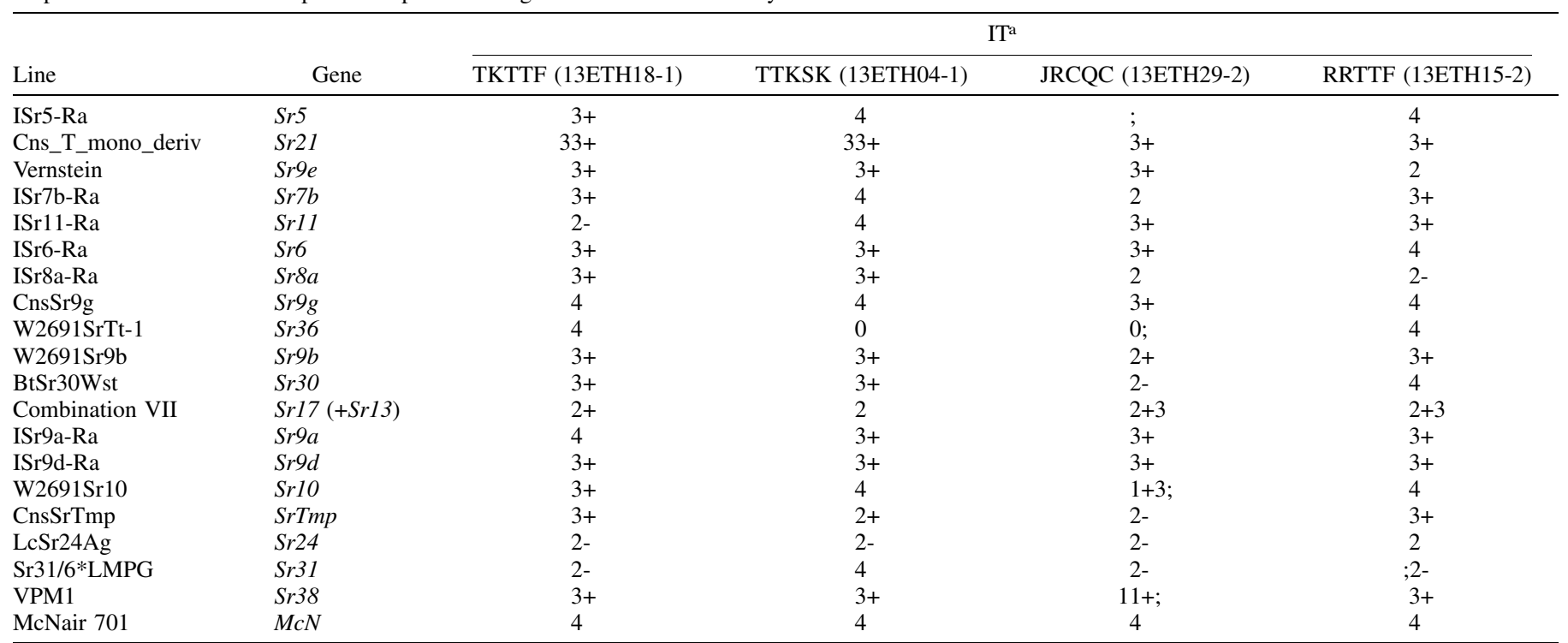

a ITs observed on seedlings at 14 days postinoculation using a 0-to-4 scale according to Stakman et al. (1962), where ITs of 0,;, 1, 2, or combinations thereof are considered as a low IT and ITs of 3 or higher are considered as a high IT.

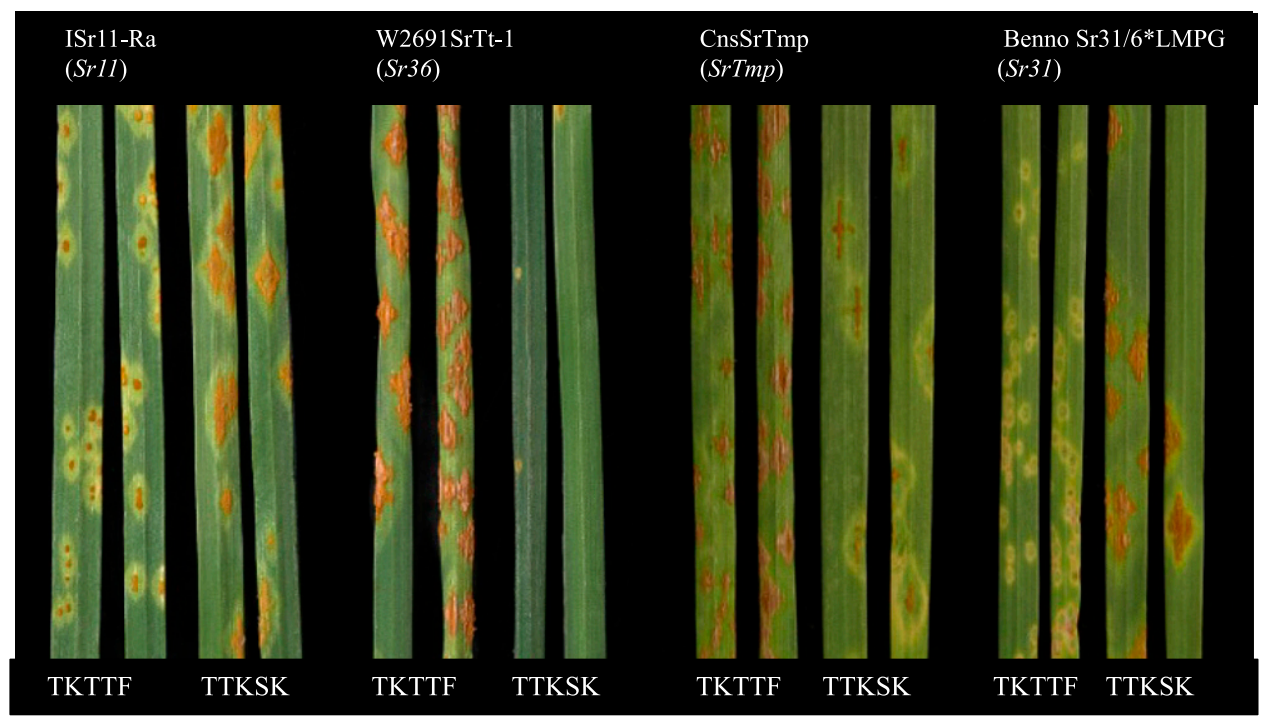

Fig. 3. Infection types on four differential lines that differentiate between races TKTTF and TTKSK of Puccinia graminis f. sp. tritici. 
test this, bulk uredinial collections from 15 samples (Bale and Arsi zones) were inoculated onto approximately 120 seedling plants of ISr11-Ra $(\mathrm{Sr} 11)$ and $\mathrm{Sr} 31 / 6 * \mathrm{LMPG}(\mathrm{Sr} 31)$. The number of uredinia and infection sites on 20 randomly selected leaves per line was counted, and the frequencies of high IT uredinia on $\mathrm{Sr} 11$ and $\mathrm{Sr} 31$ were calculated. In all cases, the frequencies of the high IT uredinia were less than $5 \%$ (Table 4), indicating low frequencies of $P$. graminis f. sp. tritici races that were not TKTTF. Randomly selected uredinia from high-IT pustules only produced isolates of race TTKSK.

Genotyping. In all, 41 isolates of 2013 Ethiopian $P$. graminis f. sp. tritici (29 isolates of race TKTTF, 6 of race TTKSK, 3 of race RRTTF, and 3 of race JRCQC) and 6 reference isolates, which

TABLE 3. Infection types (ITs) observed on lines carrying additional resistance genes to race TKTTF (isolate 13ETH18-1) of Puccinia graminis f. sp. tritici collected from Bale region of Ethiopia ${ }^{a}$

\begin{tabular}{|c|c|c|c|}
\hline Line & Gene & Type & $\begin{array}{c}\text { TKTTF } \\
\text { (13ETH18-1) }\end{array}$ \\
\hline NA101/MqSr7a & $S r 7 a$ & Bread wheat & 31 \\
\hline ST464 & $\operatorname{Sr} 13$ & Durum wheat & $22+$ \\
\hline SwSr22T.B. & $\operatorname{Sr} 22$ & Bread wheat & $2-;$ \\
\hline Agatha/9*LMPG & $\operatorname{Sr} 25$ & Bread wheat & $22+$ \\
\hline Eagle & $\operatorname{Sr} 26$ & Bread wheat & $2-;$ \\
\hline $73,214,3-1 / 9 * \mathrm{LMPG}$ & $\operatorname{Sr} 27$ & Bread wheat & $; 1$ \\
\hline Federation*4/Kavkaz & $\operatorname{Sr} 31$ & Bread wheat & $2-;$ \\
\hline ER 5155 & Sr32 & Bread wheat & 2 \\
\hline Tetra Canthatch/Ae. squarrosa & Sr33 & Bread wheat & ;2- \\
\hline $\mathrm{Mq}(2) 5 \mathrm{XG} 2919$ & Sr35 & Bread wheat & ; \\
\hline W3563 & Sr37 & Bread wheat & $1 ; 3-$ \\
\hline RL6082 & Sr39 & Bread wheat & ;2- \\
\hline RL6088 & $\mathrm{Sr} 40$ & Bread wheat & 2 \\
\hline TAF 2 & $\mathrm{Sr} 44$ & Bread wheat & $; 1$ \\
\hline CSID 5406 & $\operatorname{Sr} 45$ & Bread wheat & $; 1-$ \\
\hline DAS15 & $\operatorname{Sr} 47$ & Durum wheat & ;N \\
\hline Fed*3/Gabo*51BL.1RS-1-1 & $\operatorname{Sr} 50$ & Bread wheat & $22-$ \\
\hline Satu & SrSatu & Triticale & ; \\
\hline Fed/SrTt-3 & StTt-3 & Bread Wheat & $1+1$ \\
\hline TAM 107 & $1 A .1 R$ & Bread wheat & $2-;$ \\
\hline Leeds & $\operatorname{Sr} 9 e, 13,+$ & Durum wheat & ; \\
\hline Iumillo & $\operatorname{Sr} 9 g, 12,+$ & Durum wheat & ; \\
\hline
\end{tabular}

a ITs observed on seedlings at 14 days postinoculation using a 0-to-4 scale according to Stakman et al. (1962), where ITs of $0, ;, 1,2$, or combinations thereof are considered as a low IT and ITs of 3 or higher are considered as a high IT.

TABLE 4. Frequency of pustules exhibiting high infection type (IT) on wheat lines ISr11-Ra $(\mathrm{Sr} 11)$ and Sr31/6*LMPG (Sr31) inoculated with the original stem rust samples ${ }^{\mathrm{a}}$

\begin{tabular}{llccc}
\hline & & & \multicolumn{2}{c}{$\begin{array}{c}\text { High IT } \\
\text { pustules }(\%)\end{array}$} \\
\cline { 4 - 5 } Sample & Collection date & Predominant race & Sr11 & Sr31 \\
\hline 13ETH18 & 26 November 2013 & TKTTF & 0.51 & 0.77 \\
13ETH19 & 26 November 2013 & TKTTF & 4.42 & 3.81 \\
13ETH20 & 26 November 2013 & TKTTF & 0.53 & 0.51 \\
13ETH21 & 26 November 2013 & TKTTF & 1.37 & 1.75 \\
13ETH22 & 26 November 2013 & TKTTF & 0.89 & 0.66 \\
13ETH23 & 26 November 2013 & TKTTF & 4.05 & 3.37 \\
13ETH51 & 21 January 2014 & TKTTF & 0.00 & 0.00 \\
13ETH52 & 21 January 2014 & TKTTF & 0.00 & 0.00 \\
13ETH53 & 21 January 2014 & TKTTF & 0.00 & 0.00 \\
13ETH54 & 21 January 2014 & TKTTF & 2.33 & 2.80 \\
13ETH55 & 21 January 2014 & TKTTF & 0.00 & 0.00 \\
13ETH56 & 21 January 2014 & TKTTF & 0.00 & 0.00 \\
13ETH57 & 21 January 2014 & TKTTF & 0.00 & 0.05 \\
13ETH58 & 21 January 2014 & TKTTF & 0.00 & 0.00 \\
13ETH59 & 21 January 2014 & TKTTF & 0.00 & 0.00 \\
\hline
\end{tabular}

a ITs observed on seedlings at 14 days postinoculation using a 0 -to-4 scale according to Stakman et al. (1962), where ITs of 3 or higher are considered as a high IT. included representatives of the Ug99 race group (TTKSK, TTKST, TTTSK, and TTKSF), TRTTF, and JRCQC, were genotyped using a custom PgtSNP Chip (Table 5). After filtering, 918 SNP loci were used for analysis. Sixteen multilocus genotypes (MLGs) were identified in this set of 47 isolates. Phylogenetic analysis divided these isolates into four well-supported clades, with bootstrap values of $100 \%$ (Fig. 4). Three of these clades contained P. graminis f. sp. tritici isolates of the $\mathrm{Ug} 99$ race group (clade I), JRCQC (clade II), TRTTF or RRTTF (clade III), and the corresponding reference isolates for each of these races. The fourth clade (clade IV) contained the 29 TKTTF isolates and was composed of two well-supported branches: subclade IV-A contained 12 isolates and subclade IV-B contained 17 isolates. Although all isolates of subclade IV-A were composed of a single MLG (MLG.01), subclade IV-B contained five MLGs and was further subdivided into three well-supported branches (IV-B1, IV-B2, and IV-B3). Subclade IV-B1 contained two isolates (13ETH40-2 and 13ETH47-1), with each being a separate MLG (MLG.06 and MLG.07,

TABLE 5. Isolates of Puccinia graminis f. sp. tritici used for genotyping.

\begin{tabular}{|c|c|c|c|c|c|}
\hline Sample ID & Isolate ID & Zone, country & Year & Race & $\begin{array}{c}\text { Genetic } \\
\text { type }^{\mathrm{a}}\end{array}$ \\
\hline 13ЕTH07 & 13ЕTH07-1 & Arsi & 2013 & TKTTF & Type A \\
\hline \multirow[t]{2}{*}{ 13ETH09 } & 13ETH09-1 & Arsi & 2013 & TKTTF & Type A \\
\hline & 13ЕТН09-2 & & & & Type A \\
\hline \multirow[t]{3}{*}{ 13ETH10 } & 13ETH10-1 & East Shewa & 2013 & TKTTF & Type A \\
\hline & 13ETH10-2 & $\ldots$ & $\ldots$ & TKTTF & Type B \\
\hline & 13ETH10-3 & & & TKTTF & Type B \\
\hline \multirow[t]{3}{*}{ 13ETH13 } & 13ETH13-1 & Arsi & 2013 & TKTTF & Type A \\
\hline & 13ETH13-2 & $\ldots$ & $\ldots$ & TKTTF & Type A \\
\hline & 13ETH13-4 & $\ldots$ & & TKTTF & Type A \\
\hline \multirow[t]{2}{*}{ 13ETH15 } & 13ETH15-1 & West Goham & 2013 & RRTTF & na \\
\hline & 13ETH15-2 & $\ldots$ & $\ldots$ & RRTTF & na \\
\hline 13ETH16 & 13ETH16-1 & West Shewa & 2013 & RRTTF & na \\
\hline 13ETH17 & 13ЕТН17-2 & West Shewa & 2013 & JRCQC & na \\
\hline 13ETH18 & 13ETH18-1 & Bale & 2013 & TKTTF & Type A \\
\hline \multirow[t]{2}{*}{ 13ETH19 } & 13ETH19-1 & Bale & 2013 & TTKSK & na \\
\hline & 13ETH19-2 & & & TKTTF & Type B \\
\hline 13ЕTH20 & 13ETH20-1 & Bale & 2013 & TKTTF & Type B \\
\hline 13ETH21 & 13ETH21-1 & Bale & 2013 & TKTTF & Type B \\
\hline \multirow{2}{*}{$13 \mathrm{ETH} 22$} & 13ETH22-1 & Bale & 2013 & TKTTF & Type A \\
\hline & 13ETH22-2 & & - & TKTTF & Type A \\
\hline 13ETH23 & 13ЕТН23-1 & Bale & 2013 & TKTTF & Type B \\
\hline 13ETH25 & 13ETH25-1 & East Shewa & 2013 & JRCQC & na \\
\hline 13ЕТН31 & 13ЕТН31-2 & East Shewa & 2013 & JRCQC & na \\
\hline 13ЕТН35 & 13ЕТН35-2 & East Shewa & 2013 & TTKSK & na \\
\hline 13ЕТН39 & 13ЕТН39-1 & Bale & 2013 & TKTTF & Type B \\
\hline 13ETH40 & 13ETH40-2 & Bale & 2013 & TKTTF & Type B \\
\hline 13ETH41 & 13ETH41-1 & Bale & 2013 & TKTTF & Type B \\
\hline 13ETH42 & 13ETH42-1 & Bale & 2013 & TKTTF & Type B \\
\hline $13 \mathrm{ETH} 43$ & 13ETH43-1 & Bale & 2013 & TKTTF & Type A \\
\hline 13ETH44 & 13ETH44-2 & Bale & 2013 & TKTTF & Type B \\
\hline 13ETH45 & 13ETH45-2 & Bale & 2013 & TKTTF & Type B \\
\hline 13ETH46 & 13ЕТН46-2 & Bale & 2013 & TKTTF & Type B \\
\hline 13ETH47 & 13ETH47-1 & Bale & 2013 & TKTTF & Type B \\
\hline 13ETH48 & 13ETH48-1 & Bale & 2013 & TKTTF & Type B \\
\hline 13ETH49 & 13ETH49-1 & West Arsi & 2013 & TKTTF & Type B \\
\hline 13ETH50 & 13ЕTH50-2 & West Arsi & 2013 & TKTTF & Type A \\
\hline 13ETH60 & 13ETH60-1 & Arsi & 2013 & TTKSK & na \\
\hline 13ETH61 & 13ETH61-1 & East Shewa & 2013 & TTKSK & na \\
\hline 13ETH62 & 13ETH62-1 & West Arsi & 2013 & TKTTF & Type B \\
\hline 13ETH63 & 13ETH63-1 & Arsi & 2013 & TTKSK & na \\
\hline 13ETH64 & 13ETH64-1 & Arsi & 2013 & TTKSK & na \\
\hline$\ldots$ & 04KEN156-4b & Kenya & 2004 & TTKSK & na \\
\hline$\ldots$ & 06KEN19-V-3 ${ }^{\mathrm{b}}$ & Kenya & 2006 & TTKST & na \\
\hline$\ldots$ & 06YEM34-1 ${ }^{\mathrm{b}}$ & Yemen & 2006 & TRTTF & na \\
\hline$\ldots$ & $07 \mathrm{KEN} 24-4^{\mathrm{b}}$ & Kenya & 2007 & TTTSK & na \\
\hline$\ldots$ & 09ZIM01-5 $5^{\mathrm{b}}$ & Zimbabwe & 2009 & TTKSF & na \\
\hline$\ldots$ & $87 \mathrm{KEN} 3018-4^{\mathrm{b}}$ & Kenya & 1987 & JRCQC & na \\
\hline$\ldots$ & $75-36-700^{\mathrm{b}}$ & United States & 1975 & SCCLC & na \\
\hline$\ldots$ & $78-21-B B 463^{b}$ & United States & 1978 & DFBJ & na \\
\hline
\end{tabular}

a Abbreviation: na $=$ not applicable.

b Isolate included as reference. 
respectively). Subclade IV-B2 contained a single isolate (13ETH41-1, MLG.08) and appears to represent an intermediate branch between subclades IV-B1 and IV-B3. Subclade IV-B3 was made up of 13 isolates and two MLGs (MLG.05, 12 isolates and MLG.04, 1 isolate).

In order to further evaluate the population structure of this set of P. graminis f. sp. tritici isolates, DAPC was used (Jombart et al. 2010). The 47 P. graminis f. sp. tritici isolates formed four discrete genetic clusters corresponding to the four phylogenetic clades I to IV described above (Fig. 5). All isolates had a membership probability of 1.0, reflecting the highly clonal nature of $P$. graminis f. sp. tritici and indicating a lack of recent genetic exchange between these clusters. Furthermore, the 41 Ethiopian isolates were examined using Minimum Spanning Network analysis. The four distinct clades identified in the phylogenetic analysis are clearly shown (Fig. 6). This analysis supports the relationships within clade IV, with subclades IV-B1 and IV-B2 being intermediate between IV-A and IV-B3. Furthermore, the Minimum Spanning Network analysis suggests that clade III (TRTTF and RRTTF) is more closely related to subclade IV-B than IV-A. Given the large distances between the clades, additional $P$. graminis $\mathrm{f}$. sp. tritici isolates will need to be genotyped in order to better resolve this network and understand the evolutionary relationships.

Genetic variation between $P$. graminis f. sp. tritici isolates within the same race phenotype was also observed in the other three clades (Fig. 4; Table 5). Of the six Ethiopian isolates of race TTKSK (clade I), five of them had the same MLG (MLG.10) as the reference isolate (04KEN156-4), while one (13ETH61-1) was different (MLG.09). Each of the three remaining reference isolates for the $\mathrm{Ug} 99$ race group (isolate 06KEN19-V3 of race TTKST, isolate 07KEN24-4 of race TTTSK, and isolate 09ZIM1-5 of race TTSKF) represented distinct MLGs. No substructure was identified within this clade. Clade III (TRTTF and RRTTF) was similar, in that the three Ethiopian isolates (13ETH15-1, 13ETH15-2, and 13ETH16-1) of race RRTTF were represented by two MLGs (MLG.2 and MLG.3).

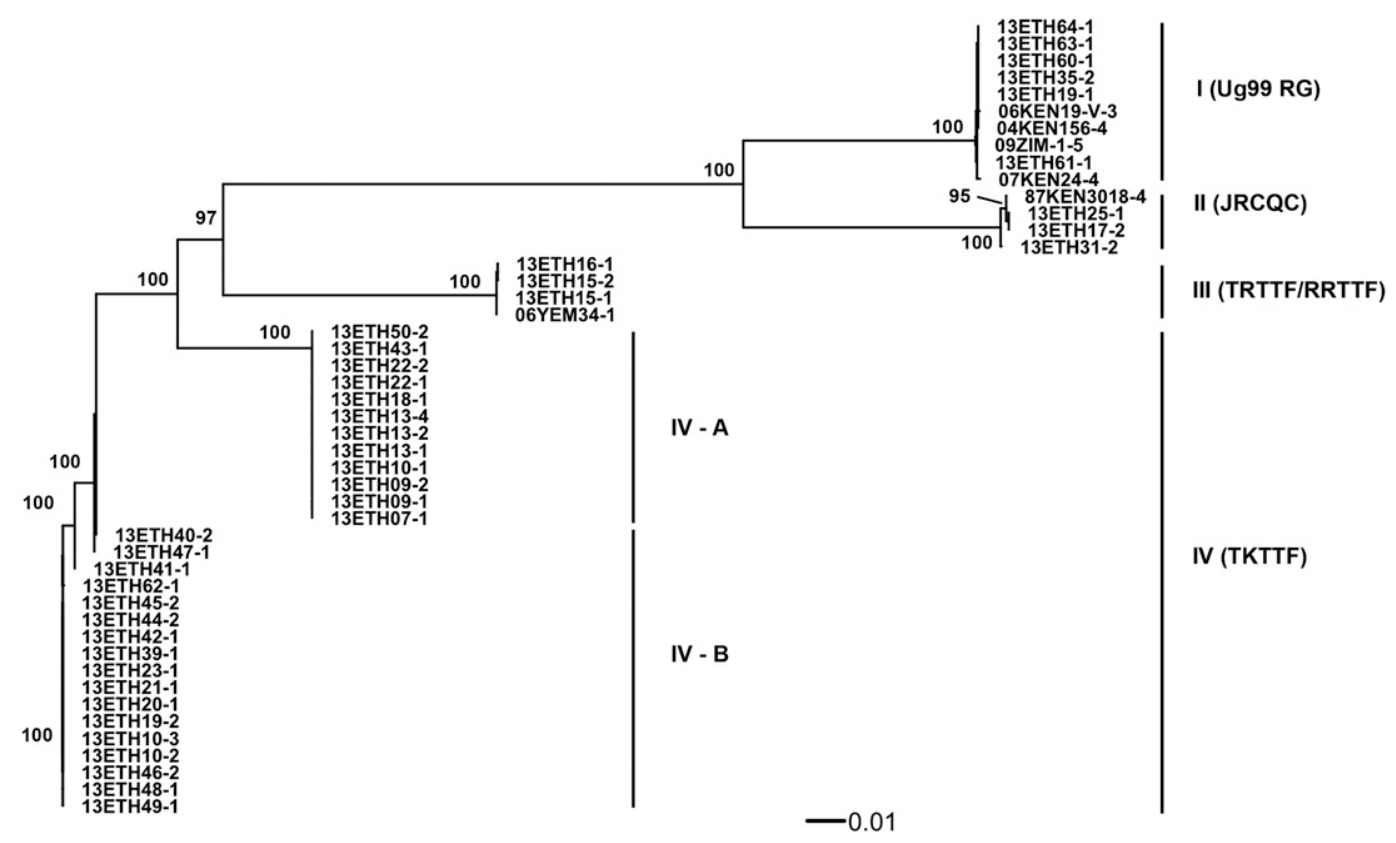

Fig. 4. Neighbor-joining phylogenetic tree of 47 isolates of Puccinia graminis f. sp. tritici based on data from 918 single-nucleotide protein loci. Clades or subclades and corresponding race or race groups are indicated. The tree is unrooted. Bootstrap values for 5,000 replicates are shown, if greater than $80 \%$. Branch lengths are measured in the number of substitutions per site.

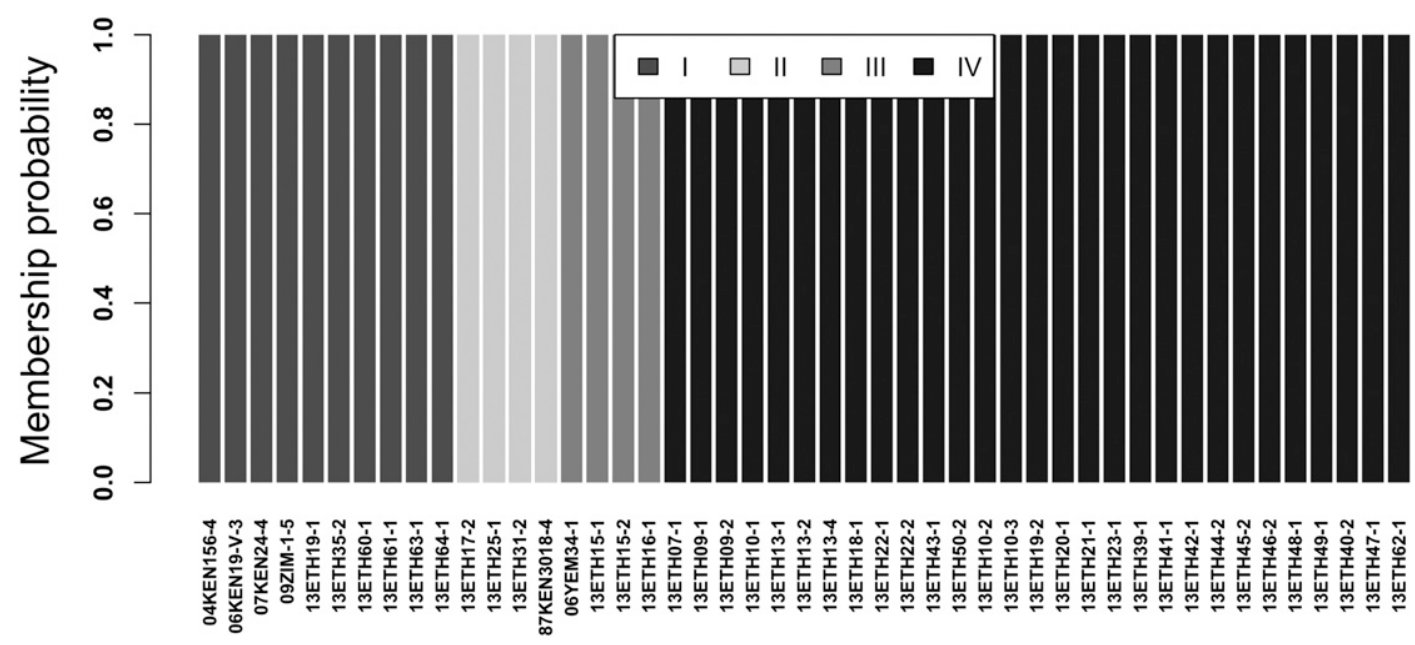

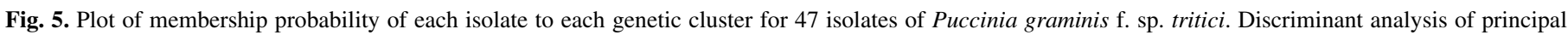

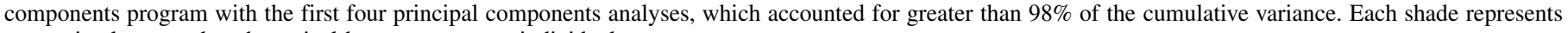
a genetic cluster and each vertical bar represents an individual. 
As in clade I, no substructure was observed. However, in clade II (JRCQC), well-supported substructure was observed between Ethiopian isolates with different MLGs. Isolate 13ETH31-2 (MLG.14) formed a subclade distinct from 13ETH17-2 and 13ETH25-1 (MLG.16) and the reference isolate 87KEN3018-4 (MLG.15).

The majority of the clade IV-B isolates (13 of 17 isolates) was collected from Bale zone (Table 5; Fig. 6). The remaining isolates were from West Arsi ( 2 isolates) and East Shewa ( 2 isolates) zones. Clade IV-A isolates were from Arsi (6 isolates), West Arsi (1 isolates), Bale (4 isolates), and East Shewa (1 isolates) zones. For six of the Ethiopian samples, multiple isolates per sample were genotyped. Only one of these samples (13ETH10) contained representatives of both IV subclades: IV-A, 13ETH10-1 and IV-B, 13ETH10-2 and 13ETH10-3. Two different MLGs were observed from isolates derived from the sample 13ETH15 (13ETH15-1, MLG.02 and 13ETH15-2, MLG.03). Isolates derived from the sample 13ETH19 were of different $P$. graminis f. sp. tritici races:
13ETH19-1 (TTKSK) and 13ETH19-2 (TKTTF). For the other three cases (13ETH09, 13ETH13, and 13ETH22), no differences in race or MLG were observed between different isolates derived from the same sample. The number of isolates of race TKTTF genotyped in this study is too small to determine whether there is significant geographical stratification between the MLGs within Ethiopia.

Reactions of breeding germplasm. Ethiopian cultivars (66 entries), elite breeding lines (66 entries) from several Ethiopian research centers, and the most recent SRRSN (the eighth and ninth SRRSN, with 274 and 457 entries, respectively) from CIMMYT were evaluated against $P$. graminis f. sp. tritici isolates of race TKTTF and TTKSK (Table 6). Of the 66 Ethiopian cultivars, 12 were resistant to isolates of race TTKSK, and 5 of these TTKSK-resistant lines were susceptible to isolates of race TKTTF. None of the 13 most widely grown cultivars in Ethiopia were resistant to isolates of both races TTKSK and TKTTF (Table 7). Of the 66 Ethiopian breeding lines, 50 showed seedling resistance to isolates of TTKSK, and 11 of these

LOCATION
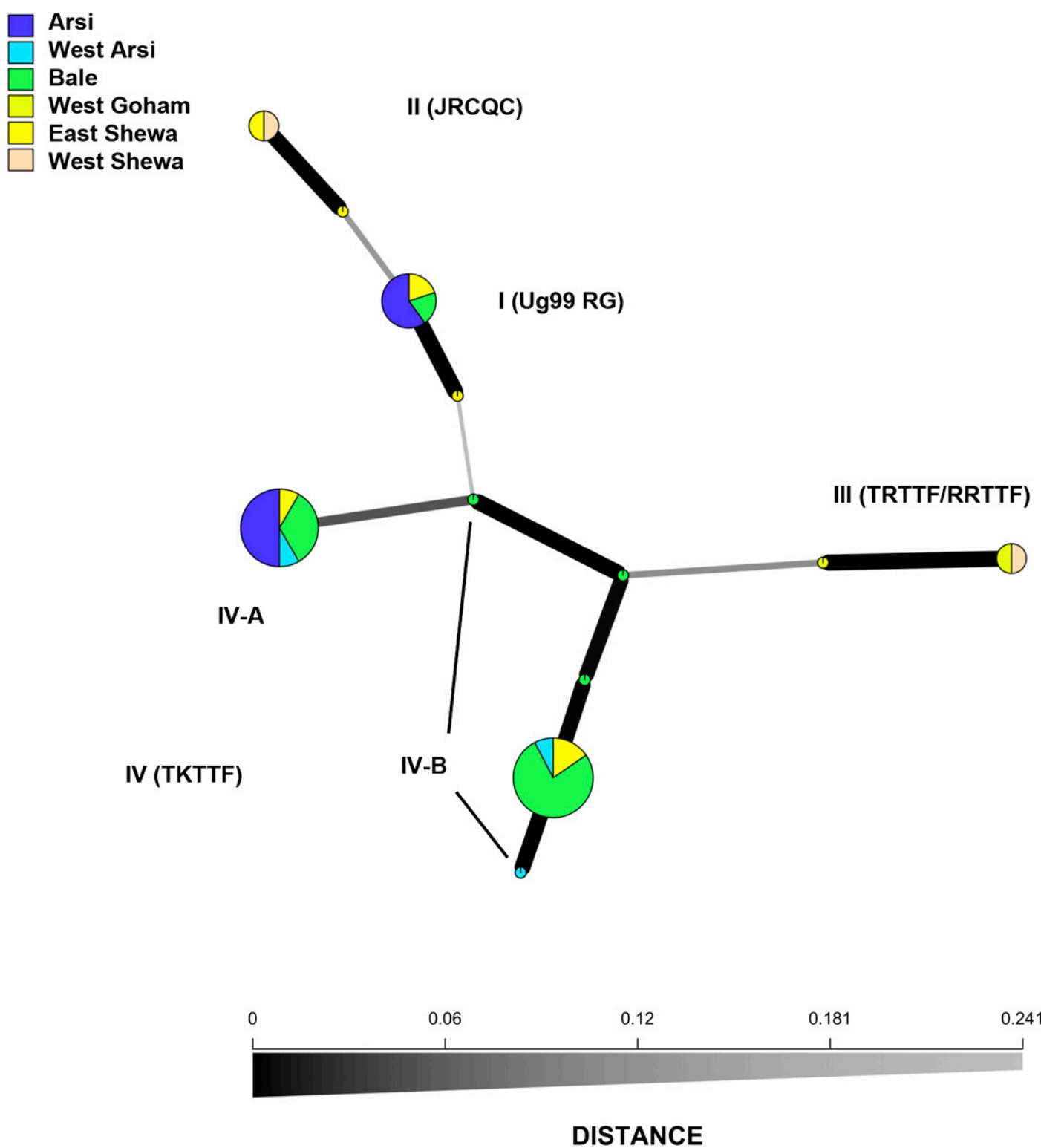

Fig. 6. Minimum spanning network of 41 Ethiopian isolates of Puccinia graminis f. sp. tritici. Origin of isolates is indicated by colors. Phylogenetic clades or subclades and corresponding race or race groups are shown. Distance is measured in the number substitutions per site. 
TTKSK-resistant lines were susceptible to isolates of TKTTF. In total, 221 and 198 of the 274 and 457 lines from the eighth and ninth SRRSN, respectively, showed seedling resistance to isolates of TTKSK. Of the 221 and 198 TTKSK-resistant lines, 21 and 31\%, respectively, were susceptible to isolates of TKTTF. If these TKTTF-susceptible lines lack adult plant resistance, they will be vulnerable to the $P$. graminis $\mathrm{f}$. sp. tritici race TKTTF if released as cultivars.

Modeling airborne spore dispersal. The results from the simulation model indicate that airborne spore dispersal during October and November 2013 occurred in the largest quantities to the southwest of the source region in Bale zone (Fig. 7). The regions of greatest simulated spore deposition concentration are coincident with the locations of the positive disease survey sites to the southwest of the Bale zone and highest levels of disease incidence on Digalu. The regions of lower simulated spore deposition concentration are coincident with the locations of the negative disease survey sites to the northwest of the Bale zone. The results are consistent with the hypothesis that the locations of high stem rust incidence on Digalu to the southwest of the core of the epidemic are the result of airborne spore dispersal from the initial outbreaks in the Bale zone.

TABLE 6. Number of wheat (Triticum aestivum) lines with resistant $(\mathrm{R})$ or susceptible (S) reactions at seedling stage to races TTKSK (04KEN156/04) and TKTTF (13ETH18-1) of Puccinia graminis f. sp. tritici

\begin{tabular}{|c|c|c|c|c|c|c|c|c|}
\hline \multirow{3}{*}{$\begin{array}{l}\text { Seeding } \\
\text { reaction to } \\
\text { TKTTF }\end{array}$} & \multicolumn{8}{|c|}{$\begin{array}{c}\text { Seedling reaction to } \\
\text { TTKSK (number of lines) }\end{array}$} \\
\hline & \multicolumn{2}{|c|}{$\begin{array}{c}\text { Ethiopian } \\
\text { breeding } \\
\text { lines }\end{array}$} & \multicolumn{2}{|c|}{$\begin{array}{l}\text { Ethiopian } \\
\text { cultivars }\end{array}$} & \multicolumn{2}{|c|}{$\begin{array}{l}\text { CIMMYT } \\
\text { eighth } \\
\text { SRRSN }\end{array}$} & \multicolumn{2}{|c|}{$\begin{array}{c}\text { CIMMYT } \\
\text { ninth } \\
\text { SRRSN }\end{array}$} \\
\hline & $\mathrm{R}$ & $S$ & $\mathrm{R}$ & $\mathrm{S}$ & $\mathrm{R}$ & $\mathrm{S}$ & $\mathrm{R}$ & $\mathrm{S}$ \\
\hline $\mathrm{R}$ & 39 & 7 & 7 & 29 & 175 & 34 & 136 & 182 \\
\hline$S$ & 11 & 9 & 5 & 25 & 46 & 19 & 62 & 77 \\
\hline Total & 50 & 16 & 12 & 54 & 221 & 53 & 198 & 259 \\
\hline
\end{tabular}

a SRRSN = Stem rust resistance screening nursery from CIMMYT (International Maize and Wheat Improvement Center, Mexico D.F., Mexico. Infection types (ITs) observed on seedlings at 14 days postinoculation using a 0-to-4 scale according to Stakman et al. (1962), where ITs of 0, ;, 1, 2, or combinations are considered as a low IT (resistant reaction) and ITs of 3 or higher are considered as a high IT (susceptible reaction).

TABLE 7. Seedling infection types (ITs) observed on common Ethiopian cultivars to isolates of Puccinia graminis f. sp. tritici races TTKSK and TKTTF

\begin{tabular}{lccc}
\hline & & \multicolumn{2}{c}{ IT $^{\mathrm{a}}$} \\
\cline { 3 - 4 } Cultivar & 2012 & $\begin{array}{c}\text { TTKSK } \\
\text { Acreage (ha) }\end{array}$ & $\begin{array}{c}\text { TKTTF } \\
(\text { 04KEN156/04) }\end{array}$ \\
\hline Digalu & 522,274 & $2+$ & $3+$ \\
Kubsa & 247,500 & $3+$ & $3+$ \\
Kakaba & 213,596 & $3+$ & $3+$ \\
Tusie & 126,042 & $3+$ & $0 ;$ \\
Madda Walabu & 116,220 & $3+$ & $0 ;$ \\
Danda'a & 89,720 & $3+$ & $33+$ \\
ET-13 A2 & 40,923 & $33+$ & $; 1+3 / 33+/ 2-$ \\
Galema & 33,000 & $3+$ & $3+$ \\
Pavon 76 & 32,738 & $3+$ & $; 2-$ \\
Dashen & 16,369 & $3+$ & $; 2-$ \\
Sofumar & 14,732 & $3+$ & $0 ;$ \\
K6295-4A & 6,548 & $3+$ & $33+$ \\
Simba & 4,911 & $3+$ & $2-$ \\
\hline
\end{tabular}

a ITs observed on seedlings at 14 days postinoculation using a 0 -to- 4 scale according to Stakman et al. (1962), where ITs of 0,;, 1, 2, or combinations are considered as a low IT (resistant reaction) and ITs of 3 or higher are considered as a high IT (susceptible reaction).

b Acreage data obtained from the CIMMYT wheat atlas on 8 May 2014 (http:// wheatatlas.org/).

\section{DISCUSSION}

The Ethiopian countrywide epidemic of stripe rust in 2010 caused on-farm losses close to $100 \%$ and estimated national losses in wheat production of at least $15 \%$. This epidemic accelerated the rapid adoption of stripe-rust-resistant Digalu, with high yield potential and stem rust resistance to $P$. graminis f. sp. tritici $\mathrm{Ug} 99$ race group. Based on seed production estimates, Digalu occupied over 0.5 million ha (approximately $31 \%$ of the production acreage) in Ethiopia in 2013 and made a major contribution to the record wheat harvest of 3.92 million tons in the 2013-14 season. Resistance to stripe rust was a key factor that enabled farmers to benefit from the above-average rainfall in the 2013-14 season (Abeyo et al. 2014). Other rust-resistant cultivars, notably recent releases such as Kakaba and Danda'a and older varieties such as Mada Walbu, ET-13, and K-6295-4A also contributed to rust control (stripe rust and $\mathrm{Ug} 99$ race group) in Ethiopia.

The stem rust resistance in Digalu is postulated to be due to SrTmp. Although SrTmp is effective against reported P. graminis f. sp. tritici races in the Ug99 race group, the gene is ineffective against $P$. graminis $\mathrm{f}$. sp. tritici race TKTTF. The narrow genetic basis of stem rust resistance in Digalu (SrTmp), although effective against $P$. graminis $\mathrm{f}$. sp. tritici race TTKSK, created a situation of vulnerability if strains with different virulence spectra appear in the country. The high virulence of $P$. graminis $\mathrm{f}$. sp. tritici race TKTTF on SrTmp, coupled with appearance in a stem-rust-conducive environment at a relatively early crop growth stage (anthesis), resulted in a rapid stem rust epidemic on Digalu in southeast Ethiopia. Major production losses resulted in the area affected by the epidemic. Initial production forecasts made by CSA in October 2013 (preepidemic) for Bale zone (core of the epidemic) were 546,213 tons, whereas actual production (postepidemic) for Bale zone reported by CSA in May 2014 was only 439,384 tons. No other mitigating factors were observed in Bale zone; hence. the negative difference of over 100,000 tons is believed to be the outcome of the stem rust epidemic caused by $P$. graminis $\mathrm{f}$. sp. tritici race TKTTF.

A high-throughput SNP array (PgtSNP Chip) was used to genotype selected isolates derived from $P$. graminis f. sp. tritici collections made in Ethiopia during the 2013-14 season. Phylogenetic analysis showed that TKTTF isolates formed a unique clade (clade IV) that was clearly distinct from the other three clades representing isolates of common $P$. graminis f. sp. tritici race types (clade I, Ug99 race group; clade II, TRTTF and RRTTF; and clade III, JRCQC) found in Ethiopia. Clade IV (TKTTF) was further subdivided into two groups (IV-A and IV-B) and composed of six MLGs. Genetic variation between isolates of the same race phenotype was also observed in samples of TTKSK, JRCQC, and RRTTF. Preliminary studies indicate that clade III (TRTTF and RRTTF) and clade IV (TKTTF) may be part of a larger lineage, and SNP genotyping of an expanded set of P. graminis f. sp. tritici isolates is being performed. This study should provide a better understanding of the relationships and evolution of these clades. However, this phylogenetic study clearly demonstrates that isolates of $P$. graminis $\mathrm{f}$. sp. tritici race TKTTF are not a result of recent mutations from common races in Ethiopia, and suggests that $P$. graminis f. sp. tritic $i$ TKTTF was either recently introduced into Ethiopia from an outside regions or has existed in Ethiopia but at a low frequency and, therefore, has gone undetected.

Very little is known about the $P$. graminis f. sp. tritici population structure and dynamics in Ethiopia. In the last decade, there has been a dramatic increase in stem rust surveillance in Ethiopia and the surrounding region due to epidemics caused by $P$. graminis $\mathrm{f}$. sp. tritici races in the Ug99 race group. The majority of stem rust samples that have been collected and characterized have come from breeding nurseries. Admassu et al. (2009) was the first to study the $P$. graminis f. sp. tritici population in Ethiopia and analyzed 
approximately 150 isolates collected from wheat fields in Arsi, Bale, and Shewa zones and northwest Ethiopia during 2006 and 2007. In this study, 22 P. graminis f. sp. tritici races were identified, with race TTKS (Ug99) being the most predominant. None of the isolates characterized by Admassu et al. (2009) had a virulence profile that matched TKTTF.

A limited set of stem rust samples $(n=33)$ was collected from Arsi and Bale zones in Ethiopia during 2012 (August to November). Recently, single-pustule isolates from this collection were race phenotyped at the GRRC (M. Hovmøller and M. Patpour, unpublished results). One of the isolates, derived from a sample from Afrisha (Bale zone), was identified to be race TKTTF. Genotyping of DNA from this sample indicated that it belongs to TKTTF subclade IV-A (L. Szabo and J. Johnson, unpublished). These results indicate that $P$. graminis f. sp. tritici race TKTTF was present in Ethiopia prior to the 2013 epidemic; however, this does not preclude the possibility that aerial incursion of urediniospores from outside of Ethiopia did occur that contributed to the epidemic.

At present, very little is known about the regional and global distribution of $P$. graminis $\mathrm{f}$. sp. tritici race TKTTF and members of this genetic lineage. The race was reported in Turkey previously (Mert et al. 2012). Clearly, increased efforts are needed to collect and characterize $P$. graminis f. sp. tritici populations not only in Africa but also globally. Advances in SNP genotyping technologies now allow the analysis of $P$. graminis $\mathrm{f}$. sp. tritici-infected wheat tissue from greenhouse-derived samples, and application of this method to single-pustule field samples should greatly enhance population genetic studies. In addition, development of SNP marker sets will provide diagnostic tools for rapid identification of critical strains of $P$. graminis f. sp. tritici.

To assess the vulnerability of Ethiopian and international bread wheat breeding materials to race TKTTF, 863 Ethiopian and CIMMYT cultivars and elite breeding lines were evaluated for seedling reaction to isolate 13ETH18-1 of TKTTF from Ethiopia. Results of these seedling evaluations indicated that 26\% (16 of 62) of the Ethiopian lines with seedling resistance to TTKSK were susceptible to race TKTTF. Similarly, 21 and $31 \%$ of the eighth and ninth SRSSN lines, respectively, with seedling TTKSK resistance were susceptible to TKTTF. A stem rust field-screening nursery with race TKTTF as the inoculum will allow determination of the presence and level of adult plant resistance. Race analyses from this study also showed that other $P$. graminis $\mathrm{f}$. sp. tritici races with significant virulence combinations such as TTKSK and RRTTF are present in Ethiopia. Wheat breeding programs in Ethiopia need to focus on developing and releasing cultivars with genes that confer resistance to a broad spectrum of virulence combinations. The use of seedling resistance genes with major effects can prevent inoculum buildup and limit the exposure of cultivars to high disease pressures in an epidemic. This study identified a group of Ethiopian advanced

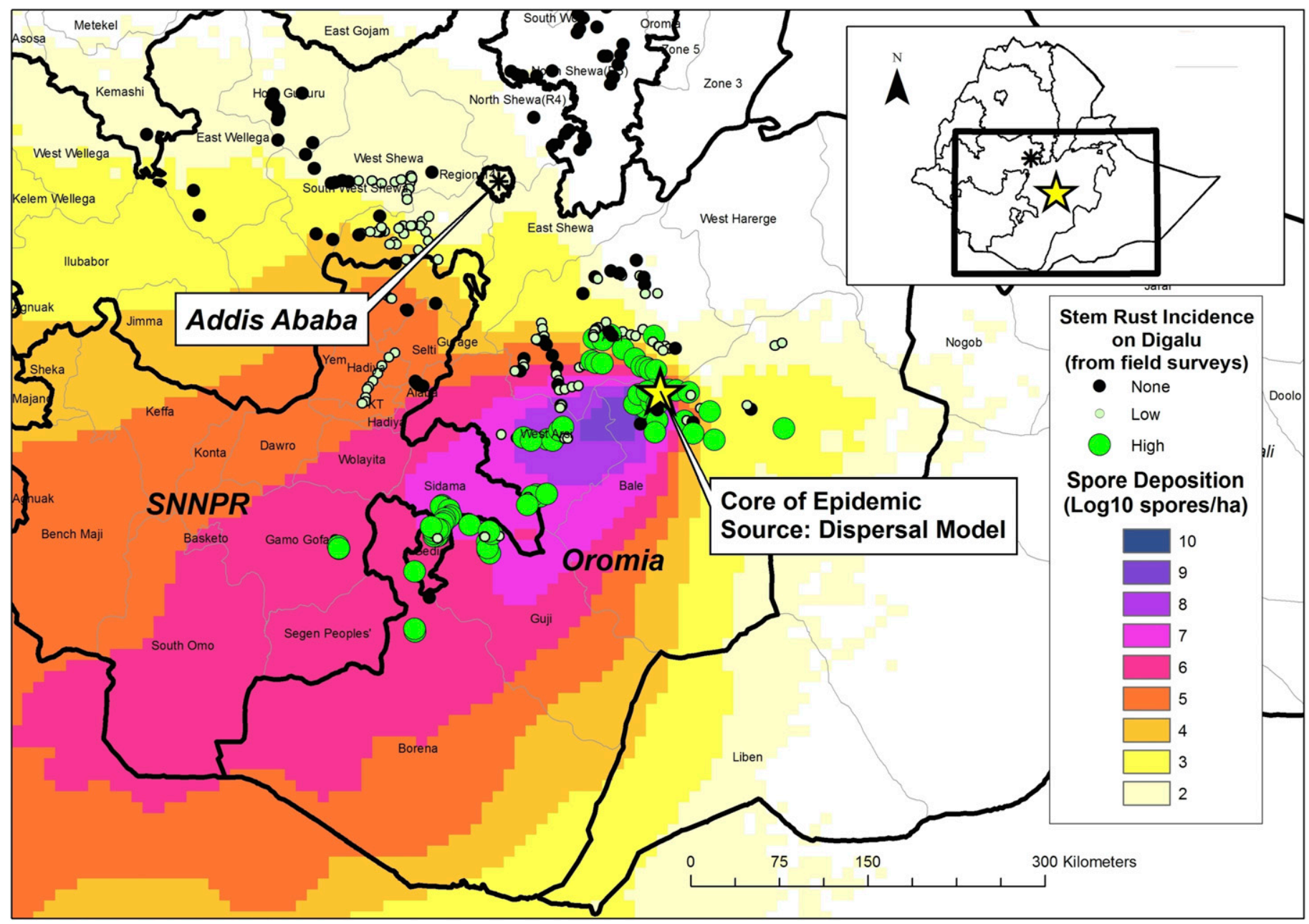

Fig. 7. Simulated airborne spore deposition for spores released from the core of epidemic (Gasera, Bale zone) in November 2013. with recorded infection sites for Puccinia graminis f. sp. tritici on Digalu. Spore deposition is displayed as the logarithm (base 10) of the spatial concentration (viable spores ha ${ }^{-1}$ ) in each grid cell ( 5 arcmin, approximately $9 \mathrm{~km}^{2}$ at the equator). Spore deposition concentration is not shown below a lower threshold of $\log _{10} 10^{2}$ spores ha $^{-1}$. Incidence of P. graminis f. sp. tritici on Digalu is derived from georeferenced field surveys. High incidence $(>40 \%)$ on Digalu is considered indicative of the presence of race TKTTF. 
breeding lines and cultivars that possess resistance to both $P$. graminis f. sp. tritici races TKTTF and TTKSK at the seedling stage

The stem rust epidemic on Digalu in southeastern and southern Ethiopia in 2013-14 developed very rapidly and spread to cover a relatively large area. A large amount of inoculum was produced and there is considerable potential both for recurrent infections in Ethiopia and also dispersal to neighboring countries. In Ethiopia, it is a near certainty that large areas will be planted to Digalu in the forthcoming seasons. Risk of interseason inoculum carry over is high, and there is an urgent need to identify and deploy diverse sources of resistance in Ethiopia. The use of a meteorologically driven airborne spore dispersal model has indicated the potential to predict disease spread in real time. Further work, not reported here, has established that meteorological conditions for spore release and dispersal are consistent among years in Ethiopia and surrounding countries during critical periods for spread. Therefore, there is a potential to develop a regional forecasting scheme using a combination of field sampling and epidemiological modeling informed by meteorological models.

The severe stem rust epidemic in southeastern and southern Ethiopia in 2013-14 on the popular variety Digalu triggered a rapid national and international response to determine the contributing factors and underlying causes. Within months of the epidemic breaking out, the causal race had been identified, likely dispersal patterns had been elucidated, and a germplasm screening program had been initiated. This is a result of worldwide efforts in recent years in stem rust surveillance to detect and monitor Ug99 and other significant races that pose a threat to wheat production and in germplasm screening to identify effective stem rust resistance for wheat improvement.

\section{ACKNOWLEDGMENTS}

This research was part of the Durable Rust Resistance in Wheat project administrated by Cornell University and funded by the Bill and Melinda Gates Foundation and the United Kingdom Department for International Development. Additional support was received from the USDA-ARS National Plant Disease Recovery Plan. We thank L. Wanschura, S. Stoxen, and M. Carter for their technical assistance. Mention of trademark, proprietary product, or vendor does not constitute a guarantee or warranty of the product by the USDA and does not imply its approval to the exclusion of other products and vendors that might also be suitable.

\section{LITERATURE CITED}

Abeyo, B., Hodson, D., Hundie, B., Woldeab, G., Girma, B., Badebo, A., Alemayehu, Y., Jobe, T., Tegegn, A., and Denbel, W. 2014. Cultivating success in Ethiopia: The contrasting stripe rust situations in 2010 and 2013. In: Abstr. BGRI 2014 Tech. Workshop. R. McIntosh and Z. Pretorius, eds. Ciudad Obregon, Mexico. Online publication. http://www. globalrust.org/sites/default/files/2014\%20BGRI\%20Plenary\%20AbstractsALL.pdf

Admassu, B., Lind, V., Friedt, W., and Ordon, F. 2009. Virulence analysis of Puccinia graminis f. sp. tritici populations in Ethiopia with special consideration of Ug99. Plant Pathol. 58:362-369.

Brown, A., Milton, S., Cullen, M. J. P., Golding, B., Mitchell, J., and Shelly, A. 2012. Unified modeling and prediction of weather and climate: A 25-year journey. Bull. Am. Meteorol. Soc. 93:1865-1877.

FAOSTAT. 2014. FAO Statistical Databases. Online publication. http://faostat.fao.org/

Fetch, T., Jr. 2009. Stem rust-A wheat killer of global proportions. Can. J. Plant Pathol. 31:149.

Iqbal, M. J., Ahmad, I., Khanzada, K. A., Ahmad, N., Rattu, A. R., Fayyaz, M., Ahmad, Y., Hakro, A. A., and Kazi, A. M. 2010. Local stem rust virulence in Pakistan and future breeding strategies. Pak. J. Bot. 43: 1999-2009.

Jin, Y., Singh, R. P., Ward, R. W., Wanyera, R., Kinyua, M., Njau, P., Fetch, T., Pretorius, Z. A., and Yahyaoui, A. 2007. Characterization of seedling infection types and adult plant infection responses of monogenic $\mathrm{Sr}$ gene lines to race TTKS of Puccinia graminis f. sp. tritici. Plant Dis. 91:10961099.

Jin, Y., Szabo, L. J., Pretorius, Z. A., Singh, R. P., Ward, R., and Fetch, T., Jr. 2008. Detection of virulence to resistance gene $\operatorname{Sr} 24$ within race TTKS of Puccinia graminis f. sp. tritici. Plant Dis. 92:923-926.

Jombart, T. 2008. adegenet: An R package for the multivariate analysis of genetic markers. Bioinformatics 24:1403-1405.

Jombart, T., Devillard, S., and Balloux, F. 2010. Discriminant analysis of principal components: A new method for the analysis of genetically structured populations. BMC Genet. 11:94-109.

Jones, A. R., Thomson, D. J., Hort, M. C., and Devenish, B. 2007. The U.K. Met Office's next-generation atmospheric dispersion model, NAME III. Pages 580-589 in: Air Pollution Modeling and its Application XVII. C. Borrego and A.-L. Norman, eds. Proc. 27th NATO/CCMS Int. Tech. Meet. Air Pollution Modelling and its Application.

Kamvar, Z. N., Tabima, J. F., and Grünwald, N. J. 2014. Poppr: An R package for genetic analysis of populations with clonal, partially clonal, and/or sexual reproduction. PeerJ 2:e281.

Mert, Z., Karakaya, A., Dusunceli, F., Akan, K., and Cetin, L. 2012. Determination of Puccinia graminis f. sp. tritici races of wheat in Turkey. Turk. J. Agric. For. 36:107-120.

Nei, M. 1972. Genetic distance between populations. Am. Nat. 106:283-292.

Nei, M. 1978. Estimation of average heterozygosity and genetic distance from a small number of individuals. Genetics 89:583-590.

Olivera, P. D., Jin, Y., Rouse, M., Badebo, A., Fetch, T., Jr., Singh, R. P., and Yahyaoui, A. 2012. Races of Puccinia graminis f. sp. tritici with combined virulence to $\mathrm{Sr} 13$ and $\mathrm{Sr} 9 \mathrm{e}$ in a field stem rust screening nursery in Ethiopia. Plant Dis. 96:623-628.

Paradis, E. 2010. pegas: An R package for population genetics with an integrated-modular approach. Bioinformatics 26:419-420.

Paradis, E., Claude, J., and Strimmer, K. 2004. APE: Analyses of phylogenetics and evolution in R language. Bioinformatics 20:289-290.

Peterson, R. F., Campbell, A. B., and Hannah, A. E. 1948. A diagrammatic scale for estimating rust intensity of leaves and stem of cereals. Can. J. Res. Sect. C 26c:496-500.

R Core Team. 2014. R: A Language and Environment for Statistical Computing. R Foundation for Statistical Computing, Vienna. Online publication. http://www.R-project.org/

Roelfs, A. P., Long, D. L., and Roberts, J. J. 1993. Races of Puccinia graminis in the United States during 1992. Plant Dis. 77:1122-1125.

Roelfs, A. P., and Martens, J. W. 1988. An international system of nomenclature for Puccinia graminis f. sp. tritici. Phytopathology 78:526-533.

Saitou, N., and Nei, M. 1987. The neighbor-joining method: A new method for reconstructing phylogenetic trees. Mol. Biol. Evol. 4:406-425.

Shank, R. 1994. Wheat stem rust and drought effects on Bale agricultural production and future prospects. Report on February 17-28 assessment. In: United Nations Emergencies Unit for Ethiopia. Addis Ababa, Ethiopia. On-line publication http://www.africa.upenn.edu/eue_web/Bale_mar.txt

Singh, R. P., Hodson, D. P., Huerta-Espino, J., Jin, Y., Bhavani, S., Njau, P., Herrera-Foessel, S., Singh, P. K., Singh, S., and Govindan, V. 2011. The emergence of Ug99 races of the stem rust fungus is a threat to world wheat production. Annu. Rev. Phytopathol. 49:465-481.

Singh, R. P., Hodson, D. P., Huerta-Espino, J., Jin, Y., Njau, P., Wanyera, R., Herrera-Foessel, S. A., and Ward, R. W. 2008. Will stem rust destroy the world's wheat crop? Adv. Agron. 98:271-309.

Stakman, E. C., Steward, D. M., and Loegering, W. Q. 1962. Identification and physiologic races of Puccinia graminis var. tritici. U. S. Dep. Agric. Agricultural Research Service E-617.

Zewde, L., Tanner, D. G., Elias, E., Gorfu, A., Tarekegne, A., Geleto, T., Yilma, Z., and Gebre, H. 1990. The relative importance of yield limiting factors on bread wheat in the Ethiopian highlands. In: Sixth Regional Wheat Workshop: For Eastern, Central and Southern Africa. D. G. Tanner, M. Van Ginkel, and W. Mwangi, eds. CIMMYT, Mexico, D.F. Online publication. http://repository.cimmyt.org/xmlui/bitstream/handle/10883/1137/ 24106.pdf?sequence $=1$ 